\title{
SENSORIUM JOURNAL
}

vol. 3, 2021

\section{SIMONDON}

ISSN: 2002-3030

Published by: LiU e-press

Edited by: Solveig Daugaard, Johan Fredrikzon, Per Israelson, Ragnild Lome, Jakob Lien and Jenny Jarlsdotter Wikström 


\section{Contents}

s. 2-4: Introduction

The editors

s. 5-17: Peer-reviewed article: Technical Culture and the Politics of Problems Stefano Daechsel

Why Simondon, Why Now? Three Interviews by Johan Fredrikzon

s. 18-27: Abstract Machines. Interview with Gary Tomlinson

s. 28-35: Simondon as a Neo-Scholastic? Interview with John Durham Peters

s. 36-47: Constrained freedom. Interview with Paul North

s. 48-51: Recommended Articles and Books

s. 52-55: Vocabulary

s. 56-59: Review: Cybernetics: The Macy Conferences (Claus Pias) Johan Fredrikzon

s. 60-77: Recension: Understanding Media Ecology (Dennis D. Cali and Lance Strate)

Per Israelson 


\section{Introduction: Why Gilbert Simondon?}

It started with curiosity: The name of the French philosopher seemed to pop up here and there, while we were working on dissertations and postdoc-projects. Not just, as we already knew, in the works of the French philosophers Gilles Deleuze, Bernard Stiegler and German media historians like Bernhard Siegert and Erich Hörl, but also in books and articles by John Durham Peters, Elisabeth Grosz and Yuk Hui. Simondon seemed to be relevant when discussing the question of technology in the Anthropocene, digging into neo-cybernetic trends within critical theory, understanding New Materialism and challenging AI-philosophy. What was it about this French philosopher that could inspire so many different thinkers and fields of thoughts?

We soon realized that we did not know very many people who had worked with the ideas of Simondon, and thus, set forth to produce some texts on him. With this issue, we do not intend to give a comprehensive introduction to Simondon's philosophy. What we hope to do, is to offer a handful of reflections upon how to use Simondon today.

We do this by publishing an article on the politics of problems in the thinking of Simondon and Gilles Deleuze, written by Stefano Daechsel and a three-part interview on Simondon's oeuvre with Yale-professors Gary Tomlinson, John Durham Peters and Paul North, conducted by Johan Fredrikzon. In addition, we have pieced together a few editorial texts: An overview of interesting articles and 
books on Simondon that we came across as we edited this volume, and a brief vocabulary of Simondonian thought.

The article and interview provide several answers to the question why Simondon is a relevant thinker today. Gary Tomlinson argues that Simondon offers key insights to evolutionary studies: $\mathrm{He}$ is able to bridge the gap between cultural and evolutionary biology. This is due to the Simondonian understanding of culture, Tomlinson argues, as something that arises in evolution and also shapes it. "We were toolmakers before we were human", as Tomlinson writes in the article "Semiotic Epicycles and Emergent Thresholds in Human Evolution" (Glass-bead.org, 2017), which he quotes in the interview.

Furthermore, Simondon flirts with what John Durham Peters calls neoThomism, a view of the history of technology that is not transcendental, nor teleologically determined or based on an idea of progress, but that is nevertheless intelligible. As John Durham Peters says in his interview: "Thomism gives you a potential of the world as an intelligible totality, much like James Joyce in Finnegan's Wake: a vision of the world as a knowable whole." Simondon's philosophy according to Durham Peters is "Aristotelian in the sense that nature has a structure which in some ways corresponds to the structure of understanding $(\ldots)$, the processes by which nature works and the processes by which technology works are analogous".

Most importantly, Simondon identifies possible strategies for resistance. Studying technology is necessary for us to act as political individuals, Stefano Daechsel argues in his article on Simondon and Deleuze. "[T]here is an urgency to Simondon's call for a technical culture that would foster a 'genuine awareness of technical realities (...)', such an awareness of technology 'possesses political and social value'." We need to delve into the technical realities, not in order to liberate ourselves from technology, but in order to modify and gain some kind of agency as technological beings. With reference to Robert de Niro's character in Terry Gilliam's film Brazil (1985), Paul North also reflects upon the agency of the individual through the figure of the tinkerer: "The kind of freedom where you can do anything, like ex nihilo creation. Simondon wants nothing to do with that. It is the middle person, the one who can take an invention and actually make it into a form of life, bring it in line with the milieu and allow each to change the other, that is interesting for Simondon."

Toward the end of the interview, North claims philosophy of technology today is looking for new resources in order to comprehend the world we live in. Daechsel 
begins his article by stating that we need a way out of our politics of defeatism today. Simondon is a useful source to go to, in both regards. We hope this volume demonstrates that.

In addition to the section on Simondon, this issue of Sensorium Journal features two reviews, on the recent complete transcript of the Macy Conferences edited by Claus Pias and two books in the series "Understanding Media Ecology". We hope you enjoy your reading!

The Editors 


\title{
Simondon's Technical Culture and a Politics of Problems
}

\section{Stefano Daechsel}

\begin{abstract}
There is a timeliness to Gilbert Simondon's call in On the Mode of Existence of Technical Objects (1958) for a technical culture that fosters a "genuine awareness of technical realities." Writing in the context of mid-20 $0^{\text {th }}$ century France, Simondon worried about a lack of technological understanding and envisaged a technical culture in which technological education would be considered as essential as literacy to meaningful participation in society. Sixty years on, the need for widespread technological awareness is greater than ever. The aim of this article is to clarify and support this claim by examining it through the lens of a politics of problems that can be found in Deleuze's Difference and Repetition (1968).
\end{abstract}

Keywords: Simondon, Deleuze, technical culture, problems 
From artificial intelligence to climate change, the big challenges of the $21^{\text {st }}$ century will revolve around the evolution and distribution of technology. The problems we face locally, nationally and globally are increasingly defined by technical conditions that feel so complex and opaque to the average person that it can induce a sense of impotence or apathy. It is against this backdrop that the thought of the $20^{\text {th }}$ century philosopher Gilbert Simondon is belatedly garnering interest within and outside of his native France.

There are many reasons for this delayed interest in Simondon, not least his influence on better known French philosophers, such as Gilles Deleuze and Bernard Stiegler, but one of his most important and timely contributions is his call in On the Mode of Existence of Technical Objects $^{*}$ for a technical culture in which technical education would be considered as essential as literacy to meaningful participation in society. Sixty years on, with the spread of technology in all facets of human existence, his project has become a political necessity.

The overarching aim of this article is to bolster Simondon's call for a technical culture by situating it within what I call a politics of problems inspired by Deleuze's unique understanding of problems and summed up as a struggle to participate in the determination of social, political and economic problems. Although Deleuze himself only hints at a politics of problems ${ }^{\dagger}$ I propose that the concept is an important component of Deleuze's political thought that complements Simondon's ideas in On the Mode of Existence of Technical Objects.

To date, the literature on Deleuze and Simondon has largely dealt with the former's debt to the latter, particularly on the concept of individuation which plays an important role in both of their respective ontologies. ${ }^{\ddagger}$ While the exploration of

\footnotetext{
* Simondon's two primary works, L'individuation à la lumière des notions de forme et d'information [Individuation in Light of Notions of Form and Information] and Du mode d'existence des objets techniques [On the Mode of Existence of Technical Objects], were both submitted in 1958 as his primary thesis and complementary thesis for the doctorat d'Etat, but an English translation of On the Mode of Existence of Technical Objects was only published in 2017 and an English version of Individuation in Light of Notions of Form and Information has just been published in 2020.

${ }^{+}$To date, the literature on Deleuze's notion of problems in Difference and Repetition has yet to address the explicitly political implications of problems that Deleuze himself alludes to on several occasions. Instead, the focus has been on the "noetic aspects" (Bowden, "Anti-Positivist Conception of Problems," 56) of Deleuzian problems - how problems operate in the formation of thoughts and the thinking subject - or their philosophical lineage through thinkers such as Kant, Nietzsche, Bergson and Heidegger (Wasser, "How to Recognise Problems?"). Consequently, more work is needed to fully flesh out the notion of a Deleuzian politics of problems.

"See Andrew Illiadis, "A New Individuation: Deleuze's Simondon Connection," Media Tropes, 4 no.1 (2013), 83-100; Sean Bowden, "Gilles Deleuze, a Reader of Gilbert Simondon," in Gilbert Simondon: Being and Technology, eds. Arne De Boever, Alex Murray, Jon Roffe and Ashley Woodward, (Edinburgh: Edinburgh University Press, 2012), 135-153; Filippo Del Lucchese, ”Monstrous Individuations: Deleuze, Simondon, and Relational Ontology," Differences 20, no. 2-3, 179-193.
} 
the connections between their ontological frameworks is interesting and important, my focus here is to combine more overtly political elements of their philosophies in order to make a case for Simondon as a timely thinker that warrants our belated interest. ${ }^{*}$

\section{A Deleuzian Politics of Problems}

Although Difference and Repetition is first and foremost an exposition of Deleuze's ontology and his theory of transcendental empiricism, it also contains flashes of a political sensibility that is geared towards the formulation and solving of problems. Deleuze develops his theory of problems most notably in the third chapter of Difference and Repetition, 'The Image of Thought,' which reads as a scathing critique of Deleuze's philosophical enemies, especially Descartes and Hegel. He also admonishes a "grotesque image of culture" founded on an impoverished understanding of problems:
We are led to believe that problems are given ready-made, and that they disappear in the responses or the solution [...] According to this infantile prejudice, the master sets a problem, our task is to solve it, and the result is accredited true or false by a powerful authority. It is also a social prejudice with the visible interest of maintaining us in an infantile state, which calls upon us to solve problems that come from elsewhere, consoling or distracting us by telling us that we have won simply by being able to respond: the problem as obstacle and the respondent as Hercules. ${ }^{\ddagger}$

In this passage, Deleuze lays out a number of challenges to the conventional understanding of a problem. Consider a multiple-choice standardised test: The person sitting the test is confronted with a question and a list of potential answers of which one is the correct response. Everything is given (ready-made) and the sole task of the testee is to correctly identify the answer, i.e., the problem's solution. Once the solution is identified, there is nothing left to do but to move on to the next question. It is possible to extend this notion of the ready-made problem to other facets of everyday life, be it the choices between consumer products - choices that

\footnotetext{
* Several cases for the importance of Simondon's work have already been made convincingly, see Muriel Combes, Gilbert Simondon and the Philosophy of the Transindividual, trans. Thomas LaMarre (Cambridge: the MIT Press, 2013); Xavier Guchet, Pour un humanisme technologique (Paris: Presses Universitaires de France, 2010); Jean-Hugues Barthélémy, "Deux points d'actualité de Simondon," Revue philosophique de la France et de l'étranger, no.3 (2006), 299-310.

${ }^{\dagger}$ Gilles Deleuze, Difference and Repetition, trans. Paul Patton (London: Continuum, 1994), 158.

${ }^{*}$ Deleuze, Difference and Repetition, 158.
} 
we are led to believe are highly consequential (Pepsi or Coke?) - or deciding between political parties at the ballot box. In all these cases, the task is to choose among a given set of options.

Deleuze maintains that our societal fixation on finding the correct solutions to ready-made problems keeps us in a state of infantilisation because "the solution necessarily follows from the complete conditions under which the problem is determined as problem, from the means and the terms which are employed in order to pose it."* How a problem is formulated and framed determines which solutions are possible. For instance, when climate change is formulated as a problem of personal consumption, the proposed solutions are either to purchase products with smaller carbon footprints or to reduce one's consumption altogether. Under this formulation, the need for sustainable alternatives to fossil fuels as our primary source of energy is ignored, as are the collective efforts to accelerate a transition away from fossil fuels, solutions that only arise when the problem is formulated differently. Thus, "a problem always finds the solution it merits, according to the conditions which determine it as a problem." ${ }^{\prime}$

Granted, ready-made problems give us some agency - we still get to choose whether to buy organic or not - but they infantilise and distract us "from the most important task, that of determining problems and realising in them our power of creation and decision." " For Deleuze, this amounts to a form of social control, treating us "[a]s if we would not remain slaves so long as we do not control the problems themselves, so long as we do not possess a right to the problems, to a participation in and management of the problems." $\$$ Who participates in the formulation of problems, in their determination, is a fundamentally political question because it is in the determination of problems that solutions are given.

Thus, Deleuze offers an outline of what I would like to call a politics of problems, a politics centred around the struggle to participate in the determination of problems. Yet, the full significance of this concept is only made apparent once we consider Deleuze's unique understanding of problems and how they fit into his wider philosophical system.

\footnotetext{
* Deleuze, Difference and Repetition, 159.

${ }^{\dagger}$ Gilles Deleuze, The Logic of Sense, trans. Mark Lester (London: The Athlone Press, 1990), 54.

* Deleuze, Difference and Repetition, 268.

${ }^{\S}$ Deleuze, Difference and Repetition, 158.
} 


\section{Deleuzian Problems}

In 1966, Deleuze wrote a highly favourable review of Simondon's book L'individu et sa genèse physico-biologique [The Individual and its Physico-Biological Genesis], an abridged version of his 1958-thesis, L'individuation à la lumière des notions de forme et d'information. He especially commends Simondon's use of the category of problem:

This category of problem acquires in Simondon's thought tremendous importance insofar as the category is endowed with an objective sense: it no longer designates a provisional state of our knowledge, an undetermined subjective concept, but a moment of being, the first pre-individual moment. ${ }^{*}$

Deleuze would go on to reiterate this point two years later in Difference and Repetition, and again in The Logic of Sense where he writes:

We must [...] break with the long habit of thought which forces us to consider the problematic as a subjective category of our knowledge or as an empirical moment which would indicate only the imperfection of our method and the unhappy necessity for us not to know ahead of time - a necessity which would disappear as we acquire knowledge. ${ }^{\dagger}$

Deleuzian problems are not "provisional and contingent movements [undergone by a subject that are] destined to disappear in the formation of knowledge" ${ }^{\ddagger}$ but ontologically independent realities that are objective; their existence does not depend on "a thinking subject who exists in an independent and prior way," as the philosopher Sean Bowden explains. ${ }^{\S}$ That said, Aubrey Wasser rightly notes that Deleuze's problems are not recognisable in the same way as "objects of sense experience".** Contrary to the latter, "[p]roblems are not unified and independently existing entities that might be perceived, conceptualized or picked-out as such by true empirical propositions" ${ }^{+\dagger}$ Deleuze himself describes problems as "multiplicities." A multiplicity is not "a combination of the many and the one, but rather an organisation belonging to the many as such, which has no need

\footnotetext{
* Gilles Deleuze, Desert Islands and Other Texts 1953-1974, trans. Michael Taormina (New York: Semiotext(e), 2004), 88.

${ }^{\dagger}$ Deleuze, Logic of Sense, 54 .

${ }^{*}$ Deleuze, Difference and Repetition, 159.

§ Sean Bowden, "An Anti-Positivist Conception of Problems," Angelaki 23, no. 2 (2018), 56.

** Aubrey Wasser, "How Do We Recognise Problems?," Deleuze Studies 11, no.1 (2017).

+' Bowden, "Anti-Positivist Conception of Problems," 56.

\# Deleuze, Difference and Repetition, 163.
} 
whatsoever of unity in order to form a system." Understood as a multiplicity, a problem is a distinct system of "differential relations between genetic elements" ${ }^{\dagger}$ but it eludes a definitive determination or resolution. As a consequence, problems can be expressed in a number of solutions depending on which genetic elements are included in a particular determination. Problems are virtual, while their solutions are actual..$^{\ddagger}$

Concerning the concept of a politics of problems, two consequences of Deleuze's theory of problems are crucial to note. First, a problem is determined as it is solved and, second, a problem does not disappear once it is solved. The first consequence rejects the notion of ready-made problems while the second challenges the conventional understanding of a problem as a temporary obstacle that vanishes once it is overcome. By treating problems as virtual multiplicities, Deleuze gives them a certain ontological independence from their actual solutions because the virtual is not exhausted when it is actualised, but persists as a "reservoir" ${ }^{\text {of genetic elements }}$ that can be expressed in new actualisations, i.e., new solutions.

Thus, seemingly resolved problems could be solved differently. For example, the nation-state continues to be the dominant solution to the problem of political power - how it should be distributed and managed across the globe - but the problem itself never ceased to exist and other solutions are possible. Solving a problem differently entails reaching into its reservoir of genetic elements to find new determinations that structure the actualisation of new solutions.

In the conclusion of Difference and Repetition, Deleuze makes explicit the political ramifications of his theory of problems. Against the politics of negation suggested by the Hegelian dialectic - in which the contradictions between a thesis and its negation (antithesis) resolve themselves in a synthesis - Deleuze proposes an affirmative politics centred on the determination of problems:

History progresses not by negation and the negation of the negation, but by deciding problems and affirming difference. It is no less bloody and cruel as a

\footnotetext{
${ }^{*}$ Deleuze, Difference and Repetition, 182.

${ }^{\dagger}$ Deleuze, Difference and Repetition, 181.

* In Difference and Repetition, Deleuze proposes a tripartite ontology that partitions the real into three registers: the virtual, the intensive and the actual. For Deleuze, the "virtual is opposed not to the real but to the actual. The virtual is fully real in so far as it is virtual." Every being has a virtual dimension, an intensive dimension and an actual dimension, and all three dimensions are equally real. A problem is the virtual dimension of a being or object that structures its actualisation by intensive differences. The agents of actualisation are intensive, but the conditions that structure actualisation are virtual. For Deleuze, "[ $t]$ he reality of the virtual is structure," but a structure that is not immutable or rigidly deterministic.

${ }^{\S}$ Deleuze, Difference and Repetition, 246.
} 
result. Only the shadows of history live by negation: the good enter into it with all the power of a posited differential or a difference affirmed; they repel shadows and deny only as the consequence of a primary positivity and affirmation [...] This is why real revolutions have the atmosphere of fêtes. Contradiction is not the weapon of the proletariat but, rather, the manner in which the bourgeoisie defends and preserves itself, the shadow behind which it maintains its claim to decide what the problems are. Contradictions are not 'resolved', they are dissipated by capturing the problem of which they reflect only the shadow.*

Political action cannot be reduced to mere opposition to an existing solution or to how a problem is formulated; it must attempt to determine problems differently, affirm new solutions and formulate new problems altogether. In Difference and Repetition, an affirmative politics of problems replaces a negative politics of opposition and contradiction. ${ }^{\dagger}$

\section{Simondon, Technics and the Politics of Problems in the $21^{\text {st }}$ Century}

What then is the link between a politics centred on the formulation of problems and Simondon's call for a technical culture? In On the Mode of Existence of Technical Objects, Simondon argues for a new humanist project centred on expanding technical education because " $[t]$ he most powerful cause of alienation in the contemporary world resides in [a] misunderstanding of the machine, which is not an alienation caused by the machine, but by the non-knowledge of its nature and its essence." ${ }^{\ddagger}$ The aim of his project is to give people the ability to meaningfully engage with their contemporary technical reality and, in so doing, update our cultural understanding of technical objects. I maintain that this project has important implications for a politics of problems in the $21^{\text {st }}$ century.

\footnotetext{
${ }^{*}$ Deleuze, Difference and Repetition, 268.

${ }^{+}$Deleuze clearly considers Simondon an ally in his struggle against the Hegelian dialectic and its emphasis on negation. In his review, Deleuze writes that "in Simondon's dialectic, the problematic replaces the negative." Deleuze, Desert Islands, 88.

${ }^{*}$ Gilbert Simondon, On the Mode of Existence of Technical Objects, trans. Cecile Malaspina and John Rogove (Minneapolis: University of Minnesota Press, 2017), 16. It is important to stress that Simondon's humanism is unconventional in that it is not anthropocentric. His project consists not only in reducing alienation among humans but also, as the title suggests, in elevating the cultural standing of technical objects from mere instruments in the service of human goals to meaningful elements of existence.
} 
For Simondon, our cultural understanding of technics is outdated because it "relies on the experience of the man working with tools." Through this instrumentalist lens, technical objects are conceived as means to an end. However, this understanding ignores a series of historical changes in the relationship between humans and technical objects that started during the industrial revolution. Not only does industrialisation see the machine replace "man as tool bearer," ${ }^{\dagger}$ it creates vast networks of technical objects that are "beyond the forces of the individual." ${ }^{\ddagger}$ For Simondon, it is the networked, or reticular, nature of modern technics that forces us to reimagine technical objects as more than instruments or means to an end:

Indeed, the reticular structures of integrated technics are no longer mere means available for an action and abstractly transportable anywhere, utilizable at any moment; one changes tools and instruments, one can construct or repair a tool oneself, but one cannot change the network, one doesn't construct a network of one's own: one can only connect to a network, adapt to it, participate in it; the network dominates and frames [enserre] the action of the individual. ${ }^{\S}$

Instead of an ensemble of means, networked technical objects are "an ensemble of conditionings of action and of incitements to act." ${ }^{* *}$ As the philosopher Muriel Combes explains, Simondon's characterization of "technicity in terms of reticularity is what allows us to make a radical break with the description of technics based on the category of means, and in sum, to break with the schema of utility, which is suited only to the tool." ${ }^{\prime \dagger}$ Technical networks condition human action and thus require a new understanding of technics as a structuring force with social and political ramifications.

Today, it would seem that the existence and significance of technical networks has penetrated into our cultural understanding of technology. And yet, instrumentalist attitudes towards technical objects and networks persist, ${ }^{*}$ and the extent to which they condition human action is difficult to establish because of a persistent lack of technological education. From the perspective of a politics of

\footnotetext{
* Simondon, On the Mode of Existence of Technical Objects, 20.

' Simondon, On the Mode of Existence of Technical Objects, 78.

* Simondon, On the Mode of Existence of Technical Objects, 119.

\$ Simondon, On the Mode of Existence of Technical Objects, 229.

** Simondon, On the Mode of Existence of Technical Objects, 229.

${ }^{+}$Combes, Philosophy of the Transindividual, 67.

\# That Mark Zuckerberg and other public-facing employees regularly refer to Facebook as a 'tool' is a case in point of this persistent instrumentalist logic.
} 
problems, this partial awareness of our technological reality is consequential because it hinders our ability to properly formulate social, political and economic problems that invariably have technological conditions. The social theorist Conor Heaney notes that, for Simondon, every new technology is both "a relation to the milieu and a modification of it, with successive modifications transforming the milieu itself and therefore the conditions of action for those within it. A transformed milieu creates new problems, stimulating further modifications."*

Simondon frames this cascading effect of modification-problem-modification as an integral part of the genesis of technics, but the same logic can be expanded beyond the realm of technical invention. The solutions to technical problems become the conditions of bigger problems, especially in the era of concrete technical networks that permeate and condition all facets of human interaction.

In certain cases, the technological component of a problem is apparent: political disinformation on the internet, cybercrime and mass surveillance technologies, to name but a few. Still, other problems have more subtle technological dimensions that can easily be overlooked, such as income inequality or attention deficit disorders. Whether the technological components of a problem are obvious or not, we run the risk of misunderstanding or ignoring them. Consequently, problems are formulated poorly and the solutions they generate are inadequate to the challenges we face. The point is not that all problems and their solutions are strictly technological, but that the technological dimensions of our problems cannot be ignored if we are to determine them better.

Underpinning this troubling state of affairs is the simple fact that most people do not participate in the formulation and resolution of technological problems. Despite the sense that every generation is more technologically literate than its predecessor, there is a big difference between being able to use technology and being able to formulate technological problems. For Simondon, the problem isn't that people don't know how to use technical objects but that most of us tend to engage with machines solely as workers or consumers. Learning how to use a new device is, more often than not, a 'ready-made' problem where the solution is given and minimal effort is required, if not expected. Not only does this reinforce an instrumentalist understanding of technics, it leaves us incapable of changing the technical networks that condition our behaviour.

\footnotetext{
"Heaney, "The disparity between culture and technics," 197.
} 
Meanwhile, the task of formulating and resolving technological problems demands more technological understanding and more material resources than most people currently possess. The outcome has been a tech-sector increasingly dominated by a handful of mega-companies that wield an immense amount of influence on the formulation of technological problems. ${ }^{*}$ The ongoing development of artificial intelligence (AI) is but one extreme example of how the concentration of the power to formulate and resolve technological problems can have serious political and social ramifications. ${ }^{\dagger}$

For these reasons, there is an urgency to Simondon's call for a technical culture that would foster a "genuine awareness of technical realities" education and technical activity. Such an awareness of technics "possesses political and social value: it can give man the means for thinking his existence and situation according to the reality that surrounds him," a reality that is profoundly technological.

Not only would we acquire "the philosophical and notional awareness of technical reality"** as a reticular and conditioning force, but a technical culture would allow more people to actively participate in the formulation and resolution of technological problems. In so doing, they would come to realise that every technical object is a solution to a problem that could be solved differently because, as Deleuze shows us, a problem is never exhausted or extinguished in its solution. This realisation opens up new horizons of technological discovery that are not subservient to market or geopolitical forces and that no longer reduce technical objects to their utility.

Already, these alternative trajectories of technological experimentation can be found in phenomena like the movement for free and open source software and, more

\footnotetext{
* In her book, The Big Nine (2019), Amy Webb explains how the future of artificial intelligence (AI) is largely being shaped by nine tech giants: six American companies (Google, Amazon, Apple, IBM, Microsoft and Facebook) and three Chinese companies (Baidu, Alibaba and Tencent). Acting under the pressure of market and governmental forces, Webb argues that these companies have placed AI on a dangerous developmental track that could turn it into a fundamentally anti-democratic technology.

${ }^{+}$In her discussion of another important French thinker of technics, Bertrand Gille, Daniela Voss notes that "[i]nvention as an individual initiative becomes more and more impossible due to the amount of scientific knowledge and laboratory equipment required, and the rising costs of research." As a result, invention "has become institutionalised in official departments financed by state agencies (military, state universities, etc.) and large corporations (corporate research unites, laboratories, adjunct foundations at universities, etc.)." Access to these institutions is guarded and the post-secondary qualifications required to be admitted as a member are made scarce by some combination of financial cost and entrance requirements.

${ }^{*}$ Simondon, On the Mode of Existence of Technical Objects 19.

${ }^{\S}$ Simondon, On the Mode of Existence of Technical Objects, 20.

${ }^{* *}$ Simondon, On the Mode of Existence of Technical Objects, 235.
} 
recently, the maker movement, a global network of people who make their own electronics and share their designs and experiences online and in person. These movements encourage people to move beyond the role of consumer to become makers and hackers who engage in the activity of invention and, in so doing, learn to pose and solve technological problems. They also resonate with Simondon's project because they depart from the paradigm of work which treats technical objects as means of production for a definite task. Instead, the maker movement and the movement for free and open source software approach technical objects as open sites of intervention and learning and their creations are designed to facilitate further experimentation rather than conceal their internal mechanisms as is often the case with commercial products. ${ }^{*}$

A challenge, however, is that both movements have been vulnerable to industry capture and have had limited success in engaging people who do not already have a professional or educational background in computer science or design. Thus, the transition from a technologically illiterate culture to the technical culture that Simondon imagines will require more radical and structural changes to our socioeconomic order than can be achieved by makers and hackers alone. Indeed, without widespread technological education in schools and major changes to the way technology is regulated and developed, it is difficult to conceive of an inclusive and participatory technical culture that would enable more people to affect the trajectory of technology and engage in a politics of problems increasingly defined by technological conditions.

\footnotetext{
*I develop this point and the relationship between the maker movement and Simondonian thought in Stefano Mazzilli-Daechsel, "Simondon and the maker movement," Culture, Theory and Critique, vol. 60, no. 3-4 (2019).
} 


\section{References}

Bardin, Andrea. Epistemology and Political Philosophy in Gilbert Simondon: Individuation, Technics, Social Systems. London: Springer, 2015.

Barthélémy, Jean-Hugues. Deux points d'actualité de Simondon, Revue philosophique de la France et de l'étranger, no.3 (2006), 299-310.

Bowden, Sean. An Anti-Positivist Conception of Problems, Angelaki 23, no. 2 (2018), 56.

Bowden, Sean. Gilles Deleuze, a Reader of Gilbert Simondon, in Gilbert Simondon: Being and Technology, eds. Arne De Boever, Alex Murray, Jon Roffe and Ashley

Woodward, Edinburgh: Edinburgh University Press, 2012, 135-153

Combes, Muriel. Gilbert Simondon and the Philosophy of the Transindividual.

Translated by Thomas LaMarre. Cambridge: the MIT Press, 2013.

DeLanda, Manuel. Intensive Science and Virtual Philosophy. London: Continuum, 2002.

Deleuze, Gilles. Desert Islands and Other Texts 1953-1974. Translated by Michael Taormina. New York: Semiotext(e), 2004.

Deleuze, Gilles. Difference and Repetition. Translated by Paul Patton. London: Continuum, 1994.

Deleuze, Gilles. The Logic of Sense. Translated by Mark Lester. London: The Athlone Press, 1990.

Del Lucchese, Filippo. Monstrous Individuations: Deleuze, Simondon, and Relational Ontology, Differences 20, no. 2-3 (2009), 179-193.

Guchet, Xavier. Pour un humanisme technologique. Paris: Presses Universitaires de France, 2010.

Heaney, Conor. The disparity between culture and technics, Culture, Theory and Critique 60, no.3-4 (2019), 193-204.

Illiadis, Andrew. A New Individuation: Deleuze's Simondon Connection, Media Tropes, 4 no.1 (2013), 83-100.

Mazzilli-Daechsel, Stefano. Simondon and the maker movement, Culture Theory and Critique 60, no 3-4 (2019), 237-249.

Simondon, Gilbert. Individuation in Light of Notions of Form and Information. Translated by Taylor Adkins. Minneapolis: University of Minnesota Press, 2020.

Simondon, Gilbert. L'individuation à la lumière des notions de forme et d'information. Grenoble: Millon, 2017.

Simondon, Gilbert. On the Mode of Existence of Technical Objects. Translated by Cécile Malaspina and John Rogove. Minneapolis: University of Minnesota Press, 2017. 
Simondon, Gilbert. Sur la technique. Paris: Presses Universitaires de France, 2014.

Voss, Daniela. Invention and capture: a critique of Simondon, Culture, Theory and Critique 60, no 3-4 (2019), 279-299.

Wasser, Aubrey. How Do We Recognise Problems?, Deleuze Studies 11, no.1 (2017), 49 .

Webb, Amy. The Big Nine: How the Tech Titans and their Thinking Machines Could Warp Humanity. New York: Public Affairs, 2019. 


\title{
1. Abstract Machines Interview with Gary Tomlinson*
}

\begin{abstract}
About Gary Tomlinson
Gary Tomlinson is John Hay Whitney Professor of Music and the Humanities and director of the Whitney Humanities Center at Yale University. Tomlinson has taught and written about the history of opera and earlymodern musical thought and practice, but also on the philosophy of history and anthropological theory. In his current research, he combines humanistic theory with evolutionary science and archaeology to search for the role of culture in the evolution of man. Following A Million Years of Music: The Emergence of Human Modernity (MIT Press, 2015), his new book Culture and the Course of Human Evolution (Chicago, 2018) deepens the theoretical framework on how culture has shaped biology.
\end{abstract}

Johan Fredrikzon: You participated in a Gilbert Simondon conference, Modes of Technical Objects, at Yale in April 2018.

Gary Tomlinson: Yes - twelve people sitting around a table for two days talking about Simondon!

\footnotetext{
* Johan Fredrikzon spent one and a half years as a visiting research assistant at the Film and Media Studies Program at Yale University 2018/2019. Some months before he arrived, a two-day workshop on Simondon was held by the Yale-Düsseldorf Working Group on Philosophy and Media, titled Modes of Technical Objects, with scholars from the US and Germany. Fredrikzon decided to engage a few of the workshop participants for this special issue of Sensorium, with the purpose to discuss perspectives on Simondon as a theoretical instrument for thinking technology, how the French philosopher matters in their work, and why there seems to be a revival in the interest in the writing of Simondon these days. On behalf of the Sensorium journal, the interviewer would like to thank the three interviewees for their generous participation.
} 
JF: Your paper was entitled "Perception et Modulation" which refers to a course given by Simondon at the École Normale Supérieure in 1968. What was your talk about?

GT: It was about the concept of "abstract machines", which is crucially interesting in Simondon's thinking. It is a Deleuzian and Guattarian notion, developed from, among others, Simondon, even though he never uses the exact term; Simondon talks about abstraction and about the technical essence. So, what is an abstract machine? It's a set of processes that arise immanently from an assembly of matter and energy. And that's sufficient to define it.

JF: OK.

GT: We can define it more specifically but I would rather give you an example that has interested me in thinking about evolution: The abstract machines playing a role in the evolution of life on earth are perfect examples of what abstract machines can be. Darwin's natural selection is the most fundamental of them: If there is inheritance, and variation in that inheritance, then, in any circumstance of limited resources, advantages will accrue to certain variations and not to others. In this way, natural selection is an abstract machine at work. In defining the modes of existence in technical objects, Simondon is trying to reach exactly the question of an abstract machine. His famous example of this is the diode and the triode. Diodes and triodes are devices for electrical amplification, invented early in the 20 th century. They were instrumental in the development of electronics, and were later replaced by transistors in consumer products. Simondon makes the point that an earlier invention limits the possibilities and complexity of how later innovations will play out. The triode is a wonderful example of that.

JF: An abstract machine almost sounds like an algorithm or an equation.

GT: Algorithm is a good word for it, I think.

JF: Is Simondon looking for something similar to what Cornelia Vismann looks for in her concept of "cultural techniques": a sort of master plan, or the sheet of rules that will then generate certain assemblages of real life phenomena?

GT: In my understanding of Simondon I would turn it around. Talk of master plans sounds more like Norbert Wiener and cybernetics to me. I am - or my Simondon is - not entirely happy with cybernetics, because of its top-down quality: Here are the rules, now let's see how they get realized. Simondon is saying something different: Here is a technical device, how did it come about? It came about by a putting together of certain components such that rules were generated, or such that the 
abstract processes sprang up immanently, automatically from the pieces that were put together.

JF: But not independently of its environment?

GT: No, right. And that brings us to another abstract machine of evolution: niche construction. Organisms come up against a selective gradient, conditioned by the affordances and constraints of their environments. At the same time, as they live their lives they change these environments. There is a feedback mechanism at work: as the niche is constructed by the organism, so the organism is constructed by the niche through the selective pressure it exerts. This is exactly what Simondon addresses in his book On the Mode of Existence of Technical Objects, when he talks about associated milieu: "We can therefore affirm that the individualization of technical beings is the condition of technical progress. This individualization is made possible by the recurrence of causality". By "recurrent causality" he means feedback - the technical object creates a milieu around itself, and is at the same time shaped and conditioned by it. This is an abstract machine that is active both in the history and development of technology and in the history of life on earth.

JF: Right.

GT: The reason I singled out Perception et Modulation in the paper at the conference - this little treatise that Simondon never published - is because in it he likens modulation to perception - modulation being what happens in a triode, for example, and perception what happens in certain organisms. Thus he identifies an abstract machine that works analogously in the technological world and the biological world. Already in the sixties he saw something that Deleuze and Guattari in $A$ Thousand Plateaus twenty years later would dwell on at great length. His approach is radical even today - when you talk to evolutionists, they struggle with this idea. The immanent processes that arise in the course of evolution - what I call abstract machines - are difficult for them to get to.

JF: Why is that?

GT: Well, partly because the abstract machines are staring them in the face. They're right at the heart of everything that they think about all the time. Many evolutionists today are opening up to, I won't say a speculative, but rather a conceptual space in order to understand the processes that ultimately arise from living organisms in an environment. This includes phenomena such as niche construction, the Darwinian algorithm of natural selection, as well as autopoiesis. Autopoiesis is fundamental to our notion of how life arose in the first place. And autopoiesis exists in the technical 
world as well, according to Simondon: Machines are essentially enabling themselves to function as machines. What interests me about Simondon is the foresightfulness of his concept of "technical essences" as a locus for this enabling. It took thirty years after him before robotics experts suddenly realized that the only way to make a robot was from the bottom up. You cannot make a robot that will do anything very interesting using a top-down guidance system.

JF: Provide it with a "world", and then it will learn structures...

GT: Exactly, and Simondon was on to that already in the 1950s. I think this is decisively different from the approach of Norbert Wiener, which, in a sense, is much more "American". It resembles American corporate views, whereas Simondon was doing something very different.

JF: I struggle with his use of the word "essences". As an undergraduate, one learns to be cautious with such words, because they often harbor ideas of technical determination. As media scholars, should we worry about Simondon talking so much about essences or does the concept mean something else to him?

GT: We're suspicious of essences because they have the patina of transcendentalism, and we don't want to go there. But there is no transcendental ingredient of technical essences in Simondon, as I understand them. Essences must be thought of in a reversed way: As immanent things within arrays of materials with flows of energy running through them. Certainly, in Deleuze and Guattari's vocabulary, there's nothing transcendental about essences. They are precisely things that arise from within assemblages. Assemblages can be machines or parts of machines, and they can be the components of an ecosystem and organisms within it.

JF: "Conway's Game of Life" is an example of a work that expresses ideas gaining traction in the 1970s, namely an attempt of scientists to imitate natural life. It is a game developed by the mathematician John Horton Conway, with no players, based on the idea of a cellular automaton by John von Neumann and Stanislaw Ulam; a basis of life with the capacity to reproduce itself and simulate a Turing machine. Using four simple rules for what automatons can do, amazingly complex patterns can arise with no external intervention. "If we can just find the algorithm here, life is going to basically start popping up in our machines...." Do you recognize this search for a grand theory in the people you work with, today?

GT: Have you heard of the Boids project in the 1980s? Craig Reynolds was trying to model the flocking of birds and schooling of fish. He put a lot of little triangles on his computer screen and programmed them to behave according to a few simple rules 
and set them in motion. The triangles started flocking just like birds. What he had discovered was seemingly immensely complex, rule-governed behaviors that in fact are generated absolutely from the bottom up, with a very few simple rules.

JF: So now we have proven that these birds and fish are really robots?

GT: No. This is what my newest book is about. In late hominin evolution the abstract machines of evolution we talked about are at work: niche construction, natural selection, and autopoiesis. There is a fourth one, for me: Peircean semiotic behavior, which I see extending out to a huge array of animals today, not just humans. I am not talking about symbolic behavior, which is arguably just a human thing, but about semiotic behavior more generally. This sign-making forms the basis of animal cultures, which build up when animals are capable of learning something in their lives that they can pass on to a future generation.

JF: Not on the gene level.

GT: Not on the gene level, no. Even though it can have an impact at the gene level across long stretches of time. But a songbird learns songs that are taught it by other birds. It tweaks the songs in specific ways, it does certain things with them and passes them on to the next generation. This is, to me, a clear instance of a rudimentary, but still complicated, animal culture. So for songbirds, not only their non-cultural behaviors in the environment, but their cultures are changing their niches. Culture enters into the niche constructive feedback.

Now, as more and more complex cultural patterns develop - and late hominins are the great example of this - you get what I call cultural epicycles. These are formalized patterns within culture that begin to stand outside the feedback cycle and influence it almost from the outside. The patterns are generated by the feedback between cultural behavior and niche, but they take on some degree of autonomy that can influence the feedback pattern as an autonomous force. So, what you have is no longer feedback at all: it is feedforward, because feedforward refers to a control mechanism. A cultural epicycle can come to look like a control mechanism that affects the feedback cycle of niche construction.

JF: Hmm...

GT: This is, admittedly, a tough concept - a complicated mechanism and probably one that only hominins have had cultures complex enough to show in its full impact. But I think it goes a long way toward explaining the tremendous difference between niche construction among hominins over the last three hundred thousand years, and all other species who have constructed their niches in the history of the earth as far 
as we can make out. Why did human cultural development take off so very, very quickly? How did that happen? I think you need first of all the biocultural mechanism - culture involved in the feedback of niche construction. But you also need something more. And this something more has to do with cultural systems forming and coalescing and taking on the kind of autonomous power I signal in the notion of a cultural epicycle. Not wholly autonomous, not transcendent, because they're generated from within, but nonetheless something that operates as a cultural system. JF: You seem to be saying that culture has had a more important part in biological evolution than is normally granted?

GT: Absolutely.

JF: And that semiotics plays a key role. In your article "Semiotic Epicycles and Emergent Thresholds in Human Evolution" (Glass-bead.org, 2017), you say that once you have started to use beads and bead making in a cultural meaning, you cannot go back to what they were before: "once the transformation had occurred, there was no undoing it - no revoking of the semiotic potential, no matter how many times it was not exploited." What does that mean?

GT: What happened in hominin evolution - and the system of bead making is an example that sprang up at a number of different times and places - is that signs, semiotic materials, were brought into an array that then formed a coherent whole, a cultural system, an epicycle that had the potential to act as a control mechanism in niche construction. It doesn't matter if there is a society that doesn't make beads. That society has still attained the semiotic capacity not only to use signs but to array them in cultural systems so that they could make beads. The materials of the world came to have new dimensions for late hominins, they sprouted new possibilities: semiotic, social, technological, and cultural possibilities all at once.

JF: But if they are not materialized, how are they retained and cultivated?

GT: Two ways. Number one: By a certain point in hominin evolution the burgeoning of cultural epicycles made cultural niche construction so powerful a force that it could eventually alter the genome, through feedback. And second: because of that capacity, humans were making cultural systems everywhere they went. Sixty to seventy thousand years ago, whether humans were making beads or not, they were making complex systems. And these systems were at once semiotic, technological and social. The capacity doesn't disappear, because the successful negotiation of every new niche humans came in contact with demanded the capacity. 
JF: So, how does this relate to the romantic idea of finding a tribe that has not seen any culture, as it were, where we'll find the pure human?

GT: Of course you couldn't find such a tribe, even though attempts are still being made today. The reason I start from a million years ago in A Million Years of Music [Tomlinson, 2015], 750,000 years before Homo sapiens existed, is because I think I can see technological patterns already in place - flint knapping and stone tool making - that in their social existence would have required certain kinds of entrainment. And this social entrainment could have provided the foundation for the later capacity to entrain to musical meters. I think you can see signs of such beginnings a million years ago, in the social relations that are suggested by the nature of stone tool making.

JF: We were "toolmakers before we were human", as you say in your paper "Semiotic Epicycles and Emergent Thresholds in Human Evolution".

GT: Exactly.

JF: This is not my own field, so I have a hard time judging whether this would be a shocking idea to bring forward to the researchers in this area.

GT: By no means shocking to all, but shocking to some of them. My work fits into what is known as the Extended Evolutionary Synthesis, and it's an extension of that, focusing on late hominin evolution. But I'm also collaborating with a wonderful evolutionary biologist here at Yale, Günter Wagner, ${ }^{*}$ who works at the intracellular level of evolution. He is interested in how certain biological features are promulgated across hundreds of millions of years with very little change: How could this happen in a free, adaptive Darwinian model? What he finds on the intracellular level are certain kinds of feedback-generated systems that come to operate as control mechanisms and that are epigenetic, not fully directed by the genome. They take on something analogous, at the biological level, to the autonomy I am talking about with the concept of "cultural epicycles". We are finding hugely interesting analogies from his micro level all the way up to the evolution of human culture.

JF: So you are bringing the niche concept into a cultural studies or humanities domain?

GT: In 2003 F. John Odling-Smee, Marcus Feldman and Kevin Laland wrote a book that is sort of the bible on niche construction. In their book, they build culture into

\footnotetext{
*Alison Richard Professor of Ecology and Evolutionary Biology; Department of Obstetrics, Gynecology and Reproductive Sciences, Yale University; and Adjunct Professor of Obstetrics and Gynecology, Wayne State University. Especially his book Homology, Genes, and Evolutionary Innovation (Princeton University Press, 2014).
} 
their model of niche construction, but, in my view, they don't have enough of a "culturalist view" of what culture is. They try to build it into their quantitative models as coefficients in their equations. But this can only work to a certain extent - Peter J. Richerson and Robert Boyd have done very interesting work along these lines, but it can only get you so far. As a culturalist I point out the limitations of the quantitative models.

JF: You try to approach it from another angle?

GT: Yes. I'm a musicologist and a humanist, but that doesn't mean I want to dispense with quantification altogether. Still, I want evolutionary biology to recognize its limitations and to understand humanists' cultural approaches. Peirce's semiotic theory is one of these.

JF: When I read Simondon, it seems as though machines have an evolution of their own. Is there an evolution of machines that is separate from cultural or biological evolution?

GT: Here we are at the matrix, right? The adaptability of the machine is one of the less defined aspects in his book on technical objects. I can see why Simondon neglected to publish his little treatise, Perception et Modulation. It's an attempt, an experiment, and it falters because it pushes too hard at the analogies between modulation in a machine or technical object and perception in an organism. You can push that analogy only so far. Are there cultures of machines? Are there lineages of machines in the same way there are lineages of organisms?

JF: He seems to say that machines can "liberate" themselves from humans to find their balance.

GT: There are very interesting possibilities there.

JF: Almost like an AI philosophy.

GT: I think in this day and age it's hard not to read Simondon that way. But my sense is that his work in the 1950 s and 1960 s was more a critique of the culture around him than a visionary AI notion.

JF: His book On the Mode of Existence of Technical Objects came out in 1958, four years after Heidegger's and Ellul's work on technology.

GT: I don't know whether Simondon was responding explicitly to Heidegger, but certainly his view is opposed to Heidegger's. We've all studied Heidegger's important, but romantically poetic essay "The Question Concerning Technology". In 1958 , Simondon is maybe not so much looking at Heidegger as at Sputnik. Looking around at a world that is overwhelmed by technology. I think he is just 
trying to make sense of what it means that technology is such a central aspect of human life. How do we bring it into philosophy? How independent are these processes from living processes?

But then, of course, you cannot escape the fact that technology is the invention of animals - and, as Simondon saw it, the invention of humans in particular. His thoughts on technology fold back into a critique of human culture and what culture is making of these things. There is something visionary about Simondon, which is why so many of us are thinking about him today. There's something speaking to us much more directly in his philosophy of technology than in Heidegger's.

JF: There is still a bit influence of Heidegger in Simondon.

GT: The two big German influences on the critique of technology - Heidegger and Benjamin before him - are compelling and famous, but Simondon is doing something decisively different. Reading Deleuze and Guattari's A Thousand Plateaus you see that Simondon's notion of abstract machines can be generalized - not always responsibly: A Thousand Plateaus is a wild book in many ways - to extend to every array of materials with energy coursing through it. There is something hugely interesting about the power of that generalization. Interesting also because it's not a transcendental move, it is immanent. For the real forebears of that kind of thinking you don't look back to the Frankfurt school and Benjamin. You look back to someone like Whitehead and his processual ontologies. That notion of ontology as process is, after all, hugely influential.

JF: Parts of Simondon's writing seem to express an aesthetics of the machine. It goes beyond fascination - as if he wants to defend the beauty of machines. Is there a notion of beauty in these abstract machines?

GT: One of my colleagues, the evolutionary biologist Richard Prum, ${ }^{*}$ devotes himself to the understanding of the evolution of beauty. For me, beauty is a problematic, deeply culturally circumscribed word. That doesn't mean I don't find beauty in the world. I am overwhelmed when I sit down and play a certain Beethoven movement at the piano. When I read with my undergraduates On the Origin of Species (1859), the conceptual beauty of Darwin's algorithm is likewise overwhelming to me - the brilliant turns of mind and speculation that enabled him to see natural selection. All of us savor beauty where we find it. For Alexander Baumgarten in the 1720 s and 1730 s, aesthetics was an embodied kind of knowledge, not a transcendent,

\footnotetext{
${ }^{*}$ William Robertson Coe Professor of Ornithology of Ecology and Evolutionary Biology, Yale. His most recent book is called The Evolution of Beauty: How Darwin's Forgotten Theory of Mate Choice Shapes the Animal World (Doubleday, 2017)
} 
romantic thing. It was precisely opposed to spiritual and "ensouled" knowledge. Exactly what is so wonderful about Simondon and about evolutionary models going all the way back to Darwin is that they are about complex systems generating something - whatever we want to call it - call it a soul if you want to - that is always embodied, always in an associated milieu, to use the term that Simondon uses about his technical objects. And it's that array of things that generates, from the bottom up, all these capacities, all these powers, all these systems, all these cultures.

JF: All this complexity?

GT: That's the best word: all this complexity. So, what's beautiful is the notion that from simple beginnings and relationships of components, and a few simple algorithms, all the complexity in the world is generated, whether technological, physical or biological. It's staggeringly beautiful to stand back and be able to contemplate that! The last paragraph of On the Origin of Species - the famous "entangled bank" - encapsulates that kind of contemplation. There is something deeply beautiful in that. 


\title{
2. Simondon as a Neo-Scholastic? Interview with John Durham Peters*
}

\begin{abstract}
About John Durham Peters
John Durham Peters is María Rosa Menocal Professor of English and of Film \& Media Studies at Yale University. Peters has been a creative force in media studies for many years and his thinking continues to influence academic environments throughout the world. His book The Marvelous Clouds: Toward a Philosophy of Elemental Media (Chicago, 2015) was an attempt to rethink the concept of media by including weather, dolphins and fire to the infrastructural landscape of digital communications and climate change. His new book, in cooperation with Kenneth Cmiel, is called Promiscuous Knowledge: Information, Image, and Other Truth Games in History (Chicago, 2020).
\end{abstract}

Johan Fredrikzon: In your opinion, is there currently a renewed interest in Simondon? Or is it a very small local phenomenon here at Yale University?

John Durham Peters: The choice of words - "renewed" - is interesting. I don't know if there ever was a great interest in Simondon. I think a lot of people respected his early work in the late fifties and the sixties, but it is people like Gilles Deleuze we

\footnotetext{
* Johan Fredrikzon spent one and a half years as a visiting research assistant at the Film and Media Studies Program at Yale University 2018/2019. Some months before he arrived, a two-day workshop on Simondon was held by the Yale-Düsseldorf Working Group on Philosophy and Media, titled Modes of Technical Objects, with scholars from the US and Germany. Fredrikzon decided to engage a few of the workshop participants for this special issue of Sensorium, with the purpose to discuss perspectives on Simondon as a theoretical instrument for thinking technology, how the French philosopher matters in their work, and why there seems to be a revival in the interest in the writing of Simondon these days. On behalf of the Sensorium journal, the interviewer would like to thank the three interviewees for their generous participation.
} 
can thank for interest in the following decades. Simondon disappeared toward the end of his lifetime, partly due to mental illness. I don't know what kind of psychiatric condition it was, but I don't think the seventies and eighties were very productive, and he died at sixty-five in 1989. There is a memoir online written by his daughter, who puts a positive spin on it but he seems to have struggled.

The reason I say this, is that - perhaps this is your next question - why Simondon? Obviously, he is a subtle theorist of technology who is not Heidegger. And with Heidegger you always have to do a toxicology report, if you can forgive me the metaphor. You have to figure out how much poison there is with his genius. Not just because of his Nazism and his Anti-Semitism but just because of the idiosyncrasy of his project, the obscurity of his language, the kind of poor personal judgement that he seems to have shown throughout his life together with his astonishing speculative imagination.

JF: And the hordes of Heideggerians you have to consider...

JDP: Yes. But there are a lot of Heideggerians who welcome Simondon. I was surprised to discover a very flattering citation to Simondon in Herbert Marcuse's One Dimensional Man from 1964.

JF: Simondon wants to bring technology on as a subject of philosophy. As does Heidegger. Are they similar in that respect?

JDP: That is true. If you want to theorize Being you have to theorize ontology and perhaps also technology, which is a pretty radical idea. Thus, the questions of physis and techne is important in Heidegger's "Question concerning technology". I am hearing a related distinction a lot these days, the grown and the made. Heidegger says that physis, or the grown, is that which comes into being on its own whereas techne comes into being by means of means. It needs an instrument. It needs some kind of "maker", an artificer.

JF: A coming together of elements.

JDP: Exactly. And remember that the word technology is famously tangled in English, in a way that does not really exist either in French or in German - Technik in German and technique in French express instead a productive ambiguity. ${ }^{*}$ think that is one reason both Heidegger and Simondon seem refreshing. They are always interested in the "sweet spot" where technology and technique converge.

JF: Simondon seems to be talking about technology as a way of understanding.

\footnotetext{
* In his book Marvelous Clouds, Peters gives a definition of the contrast between technology and technique: Technology has a durable base, whereas technique does not. Dolphins, for example, have technique but no technology.
} 
JDP: When I was a beginning doctoral student, we did an exercise to find a concept that could be researched - and I told my professor that my concept was technology. He said: "Sorry, you can't do that, technology is not a concept, it is a field of study." In 1861 when M.I.T. - Massachusetts Institute of Technology was named technology meant the study of the industrial arts, engineering. It didn't mean devices and gadgets.

So Heidegger published his "Question" lecture in 1954, Simondon four years later, and Simondon seems to be a response to Heidegger's work. But I really don't know how influenced he was. My very simplified definition is: Heidegger + Norbert Wiener $=$ Simondon. Which is not entirely fair. But Heidegger clearly knows something about cybernetics. He talks about it, of course, in the Der Spiegel-interview from 1966. Simondon really worked through cybernetics. He tried to figure out what it means to have a system which is indifferent to biology and machines, that deals with the completely radical insight of Wiener: "the ontological flattening" between machine, animal, human. The crazy idea I floated in our Simondon-workshop was that he is a neo-scholastic.

JF: Why neo-scholastic?

JDP: I'm out on the limb here as no Simondon expert - but it is a kind of classic cliché about post war France that you are either a communist or a Christian. Simondon is not a communist. I do not know if he is a Christian or not, but he is certainly sympathetic to medieval modes of thought about systematizing ontology and meta-stability. With Simondon there seems to be a kind of love of neo-Thomist abstraction. I'm not going to make a strong argument about this.

JF: Sounds interesting. A neo-scholastic and a neo-Aristotelian.

JDP: Neo-scholastic and a neo-Aristotelian are probably the same thing. Neoscholastic is a subset of neo-Aristotelian because there are so many ways to be neoAristotelian: You can make the argument that Hegel is a neo-Aristotelian, Marx is a neo-Aristotelian, John Dewey is a neo-Aristotelian, Hannah Arendt is a neoAristotelian, Heidegger is a neo-Aristotelian, but they are all quite different. Scholastic is a much more specific version. In the mid-twentieth century you had this florescence of neo-Thomist thinkers, many of them French. Jacques Meritain, most famously, who had a huge influence on McLuhan - I think of McLuhan as being a neo-Thomist. McLuhan will basically say this at various points, for example in an essay on Thomas Aquinas and James Joyce: Thomism gives you a potential of the world as an intelligible totality, much like James Joyce in Finnegan's Wake: a vision of 
the world as a knowable whole. For Simondon as well, the world is always intelligible on some level. There are breakdowns, meta-stability, systemic potentials for breakdowns, but there is not the existential haze of humans willfully imposing meaning on something which is inherently meaningless. It is Aristotelian in the sense that nature has a structure which in some ways corresponds to the structure of understanding. For a scholastic, that homology is due to God, of course. I'm not sure that Simondon goes that far, but the processes by which nature works and the processes by which technology works are analogous.

JF: Right. For one thing, that seems like an ambition that environmental studies tried to move away from in the eighties, which is to say that the ecological system is not all harmony. But sure, intelligibility and harmony is not necessarily the same thing.

JDP: One way to think about it is that Simondon is not a Nietzschean - Nietzsche is obviously not a neo-scholastic. Simondon is not a Derridean, although you could find similarities, but he does not particularly think about discourse and power. Simondon has a confidence in science, that it has the power to explicate the universe at some level.

JF: Simondon also - to build on what you said before - has a sort of aesthetic framework. He does not just want to grant technology a more reasonable spot in the history of philosophy, he is also expressing - I can only think of it in aesthetic terms - a vision of sorts. Like he is saying: We should find a theory of the evolution of technical objects. As undergraduates, we have learned to think of people that aestheticize technology as a warning sign.

JDP: The classic Walter Benjamin line: Critical theory says you are a fascist if you aestheticize technology.

JF: More or less. So where does that leave us, if we grant that Simondon harbors ideas of this kind?

JDP: Interesting question. For McLuhan the intelligibility of the universe is very much a question of beauty. Because order is beautiful. Cosmos gives us cosmetic. In ancient Greek cosmos doesn't just mean order, it means beauty. But McLuhan clearly has sympathies with fascist aesthetics, literally, he has sympathies for people like Wyndham Lewis or Ezra Pound, who were both explicit fascists. But there are ways in which you could uphold the vision of cosmic beauty without being a fascist. And for me, the way you do that, is by being an evolutionist. 
Do you know Charles Hartshorne? Hartshorne is a Peircean, he edited Peirce's papers, the first round in the 1920s and 1930s. He was also a world class ornithologist. He wrote a really interesting book about bird song, Born to Sing: An Interpretation and World Survey of Bird Song (Indiana Univ Press, 1974/1992), which I just love because it is about a minimal unit of a technical object - a bird song -, which is at once art/techne and involved in the evolutionary process.

JF: What about Simondon's concept of essentialism? Should we worry about that? JDP: It is called scholasticism. Essentia.

JF: To me, part of this reads "open ended", but then part of it seems to suggest some sort of essence to which technology is striving. Simondon does not use the word "fulfilment" or "completion", but he expresses similar ideas: "this object has now reached this individualized state, it is on its way to an even better stage where it won't have to be ordered around or managed by man". According to this reading of Simondon, we have to "liberate"- this is also the wrong term - technical objects from being slaves of humanity by means of evolutionary process, reach higher stages of being where they will be, in a sense, "free". This would be equivalent of their true nature.

JDP: This is also maybe where he could be seen as a Marxist...

JF: Yes, in a way.

JDP: His critique of hylomorphism ${ }^{*}$ is Marxist. Simondon argues that matter is not dominated by ideas. He almost sounds like John Dewey when he says that hylomorphism arises out of a slave society and that we need to understand that these doctrines have a kind of social "stain" or a social infrastructure to them. It is a program not of liberating the servers, but the machines of our labor. They are in need of liberation too.

JF: I think his thought is very interesting and fresh, certainly in mid 20 th century. But also potentially problematic.

JDP: Is not essence for Simondon provisional? It is very different from a kind of scholastic essence that is eternal and unchangeable.

JF: But what is essence if it does not have those qualities?

JDP: It can be historical.

JF: It sounds like something Ian Hacking would say.

\footnotetext{
* Hylomorphism: The doctrine that physical objects result from the combination of matter and form. From hylo- 'matter' + Greek morphe 'form'.
} 
JDP: Like Ian Hacking would say, or what Marx and Hegel would say. Marx tries to decapitate Hegel. Hegel tries to decapitate Aristotle. Even Aristotle - to be fair to him - has a very dynamic sense of essence. Things are coming into being. It is easy to try to platonize Aristotle and make him sound fixed. For Simondon, there is not one vacuum tube, one steam engine, which is going to be the ultimate engine.

JF: Maybe the problem lies in the translation.

JDP: The question of essence is a classic in a Marxist philosophy of history. Marx says that communism is the riddle of history solved. And Hegel says that history will come to an end. What does that mean? Do things stop happening? Obviously, they cannot: it does not make any sense. Could we just say that Simondon has drunk the post war Kool-Aid of believing that automation is the ultimate telos of labor? Many people believed this. Marcuse believed it, Isaac Asimov believed it. People of very different political orientation thought work was going to be made obsolete. And I think Simondon must be seen as part of this stream of thought. Hannah Arendt said something similar in the Human Condition in 1958, the same year the On the Mode... was published. John Kenneth Galbraith also, the liberal economist. It is amazing to see the consensus among different minded people.

JF: I wonder if philosophers of artificial intelligence are interested in Simondon, people on the intellectual side of Kurzweil.

JDP: Certainly in Germany. For six years I served as a member of the board of the IKKM, Internationales Kolleg für Kulturtechnikforschung und Medienphilosophie, at the Bauhaus Universität in Weimar, and went there every year. Weimar is a great place to pick up on trends, as Bernhard Siegert once noted, a person who is himself pushing Simondon as a forgotten philosopher of technology. Michael Cuntz, who was at our Simondon conference, translated On the mode.. into German, ${ }^{*}$ because there was so much interest.

JF: Like you said: he is not Heidegger.

JDP: You don't have to detox.

JF: Would you say that the concept of "cultural techniques" by Siegert partly builds on ideas by Simondon?

JDP: I do not want to be too reductive to my friends at Weimar, but I see cultural techniques as essentially penance for Kittlerian exaggeration.

JF: I do too. But not only that.

* Die Existenzweise technischer Objekte; Die Existenzweise technischer Objekte (Diaphanes, 2012) 
JDP: Not only. It is partly the polemical thing about the "sogennanten Menschen" [so-called people]. Kittler systematically hated sociology and Bernhard Siegert still has his guard up. But he really likes anthropology - if you see it as a neo-Hegelian question of "Was ist ein Mensch?" [what is man?]. A conference in Weimar had this title, "Was wäre der Mensch?" [what would man be?].

JF: Speaking of anthropology: did not Claude Lévi-Strauss take part in bringing cybernetics to France?

JDP: Levi-Strauss wrote a great essay called The mathematics of man [1954], and once lived in the same apartment building as Claude Shannon in New York City, according to Erich Hörl. It is not clear that they met, but Hörl has it that a neighbor told Levi-Strauss that someone else in the building was trying to build an artificial brain. There are many of these links. Benoit Mandelbrot seems to have been Wiener's intellectual broker in France. And Jean Hyppolite, Foucault's teacher, was totally into cybernetics. For someone like Lacan, cybernetics is absolutely essential for figuring out what he is doing. How do you count to one, how do you count to two? He says most people cannot count to two. He is thinking in terms of set theory. And Jakobson, clearly, is important.

JF: He was in New York, was he not?

JDP: Yes, during the 19940s, but moved to Harvard in 1949. Lily Kay, Who Wrote the Book of Life? (Stanford Univ Press, 1999) has got some really good stuff on Jakobson and Levi-Strauss from a DNA angle.

JF: And Foucault was much more into cybernetics than people would grant. JDP: Absolutely. His 1966 essay Message ou bruit ${ }^{*}$ on medical practice uses the language of information theory and code. Every Kittlerian can see the cybernetics in Foucault.

JF: I find that a lot of these people in France do not want to talk about cybernetics, even though it is very central for their thinking.

JDP: This is described in The zero and the one by Jérome Segal. It is 900 pages about cybernetics in $50 \mathrm{~s}$ and $60 \mathrm{~s}$ in France. ${ }^{\dagger}$ He has got everybody in there, among them The Bourbaki group, where Simone Weil's brother is a member. They are five or six loosely connected authors who publish revolutionary stuff on mathematics under the name Nicolas Bourbaki, who does not exist. And they are rethinking set theory,

\footnotetext{
* Lecture by Foucault, 22 October, 1966.

${ }^{\dagger}$ Le Zéro et le Un. Histoire de la notion scientifique d'information au 20e siècle, Èditions Syllepse, 2003.
} 
for example. Bernard Geoghegan is also unearthing the French connection to cybernetics.

JF: You mentioned McLuhan before. Simondon and McLuhan seem to be working with different ideas of ecology: McLuhan sees meaning, content, errors and messages as crucial, whereas Simondon worries not so much about those things. Do they have a concept of ecology that is more or less similar or not?

JDP: That is a great question. I do not know, is my answer. But when I read "ecology" in McLuhan I often think it is metaphorical. When I read "ecology" in Innis I think he knows something about beavers and trees - he in other words expresses a much more environmentally informed sense of ecology. McLuhan is normative. Simondon seems much more aligned with system theory. You can have a "multi final" outcome in the ecological system of Simondon. McLuhan's ecology is actually much more a "pathology" than an "ecology", because he is interested in systems that stress out or get overloaded. Which is not foreign to ecology - there is all kinds of extinction, overload, and eutrophication and bad feedback loops -, but this is different. There was a great talk at a recent conference in Toronto about the influence of Hans Selye, who was an émigré doctor and leading theorist of stress teaching in Montreal, who McLuhan either knew or talked to. It is very clear that McLuhan thinks that media are stress-inducing.

JF: Simondon does not worry about mass media.

JDP: Well, he has a nice essay about cinema which I thought was really smart. Although Francesco Casetti, department chair at Film and Media Studies Program here at Yale, says he was pretty much drawing upon Georges Sadoul - the standard textbook French cinema theorist in the 1950s. I thought he said some really interesting things about "massification": What does it mean to have one message going to many people? It is not as sustained as in McLuhan, by any means, but it is not fair to say that Simondon does not engage with mass media. 


\title{
3. Constrained Freedom Interview with Paul North*
}

\begin{abstract}
About Paul North
Paul North is Professor at the Department of Germanic Languages \& Literatures at Yale University. He teaches on media and literature from Ancient Greece through the romantic and enlightenment traditions into 2oth century literary and critical theory. In The Yield: Kafka's Atheological Reformation (Stanford, 2015) North presented a largely unknown Kafka based on readings of the famous writer's theoretical works at the end of World War I. Paul North's new book, Bizarre Privileged Items in the Universe: The Logic of Likeness (Zone Books, 2021) diverges from centuries of thought focused on the idea of difference to engage deeply with the concept of likeness: in evolution, in natural and social worlds, in language and in art. More on: paulnorth.org.
\end{abstract}

Johan Fredrikzon: You have called Simondon the inversion of Heidegger. Writing at roughly the same time, was Simondon directly influenced by Heidegger?

Paul North: Well, the fifties in France was a time of transition, when everyone was in love with Heidegger. Simondon's On the Mode of Existence of Technical Objects and parts of Being and Time share an idea that the world is interactive, and that tools,

\footnotetext{
* Johan Fredrikzon spent one and a half years as a visiting research assistant at the Film and Media Studies Program at Yale University 2018/2019. Some months before he arrived, a two-day workshop on Simondon was held by the Yale-Düsseldorf Working Group on Philosophy and Media, titled Modes of Technical Objects, with scholars from the US and Germany. Fredrikzon decided to engage a few of the workshop participants for this special issue of Sensorium, with the purpose to discuss perspectives on Simondon as a theoretical instrument for thinking technology, how the French philosopher matters in their work, and why there seems to be a revival in the interest in the writing of Simondon these days. On behalf of the Sensorium journal, the interviewer would like to thank the three interviewees for their generous participation.
} 
which are the machines of Being and Time, constitute existence just as much as they happen to lie around in it. Technology in Being and Time are circuits of activity and purpose that tools participate in, and that constitute human beings. Simondon is saying something very similar in his book, On the Mode...: There is an interactive freedom that gives rise to an interactive history in which there is a mutual constitution, where the skill of the human beings and the knowledge of human beings around machines - and machines themselves - interrelate in complex patterns. Machines relate to other machines, to their forbears, to their models, to the early innovations of things in this peculiar symbiosis.

I think Simondon recognized that philosophy had not caught up with this fact. A good example is Heidegger's The Question Concerning Technology, that poses questions in a vocabulary that goes back to ancient Greece. In a sense, Simondon drew upon the Greeks as well: take a concept like hypertele which comes up later in On the Mode... Hypertele is a description of the experience of a technological object. Simondon adopts Greek vocabulary, but he does not say that the Greeks knew the authentic relationship to technology. He is saying: Here is a name that we can cobble together like we do for technical objects. The name is a little machine. So we take a technical name and make a philosophical one out of it, and thereby we make philosophy more like technology, we help philosophy show us that it is like technology. This is quite the opposite of Heidegger, trying to capture technology in an ontological vocabulary. Hypertele is something that really interests me, particularly how the functionality of a technical object goes well beyond its "function". Which is to say, a particular use of a certain technical object does not exhaust its potential application.

JF: Heidegger would say that if we only look at the instrumental aspect of technology, we are missing the core idea of that technology. He has this idea that we used to have a simpler, more authentic technology in earlier periods, which changed with industrialization. Because of this development, we need to ask deeper questions about technology. So let us not look at functionality, let us not look at instrumentation, let us rather look at the way that our world is technological at the core.

PN: Well, here is a difference then. Heidegger thinks that the originary of technology is a phenomenological process, where it brings an entity to light - makes something appear: How do we get these particular beings? Tikto-in Greek, technology is the birth of beings. Simondon, you could say, is interested in a similar 
question - how do we get these technical objects? But instead of relying on a quasimetaphysical process - the birth to presence of beings - he posits instead a free interaction between a technician and a set of technical possibilities that are built into a particular object. So, this is very, very different from Heidegger. The aim is not to make a world or show how the world is made, the aim is to show how the technical object has a sort of life.

$\mathrm{JF}:$ A trajectory?

PN: It has a trajectory, and that trajectory interacts with human culture in such a way that they mutually determine one another. And that is something Heidegger would never say. He thinks that these technical objects would be the embodiment of a certain interpretation. But not that the machine interprets us.

JF: Some parts of On the Mode of Existence of Technical Objects to me sounds very "essentialistic," if that is the word.

PN: Simondon does use the word essence, but essence is just the generative trajectory of a certain technical object - there is no essence beyond the particular historical life of the object. He is interested in telling you how those generative trajectories come about. The essence is not the function, shape or substance of the object. It is the how of its development. Take for example a carburetor. The idea of such a machine emerges out of an intuition of the way fuel could be delivered to an internal combustion engine. The carburetor is there, its shape a ghost looming in the need to deliver fuel from here to there, within certain technical constraints. That intuition is originally very rough, and the parts to build a carburetor are taken from other machines. Once that initial configuration is set up, this determines in part what can possibly be developed out of it, but only partly, because the constraints come both from the object in its nascent stage outward to the technician and also from the environment, which he calls - quoting his teacher Canguilhem - "milieu". The milieu includes everything from the kind of life practices of the technicians to the tools available in the lab. A reciprocal giving of possibilities take a certain trajectory given the initial shape. And the essence is the trajectory itself.

In other words, there is not a kind of active interpretation or a free refusal of the status quo, as it would be for Heidegger. A technical object is rather a concrete intuition, if you can imagine such a thing, the projection of a need in parts and linkages and transferals of motion.

JF: It sounds like it is still fairly determined. 
PN: It is a very complicated play of determination and freedom, that is for sure. Simondon is not so naïve as to think there is total freedom. Nor is he a Hegelian. Obviously, history is littered with failed technical projects. To succeed requires the liberty to fail. That said, it is also not surprising if a carburetor works out the way it should. It's already in the reciprocal relationship of milieu, already made technical objects, and the intuited need. But it is also the case that when the carburetor is first imagined, and then first instantiated, it is not a model of the shape that the carburetor will take - it is merely a departure point for future adjustments. So, the form of the need and the form of the technical object is not fixed and it is not predetermined by the need. Need and object grow together through tinkering.

JF: Simondon seems to be interested in "liberation" of the technological object. Sometimes he reminds me of philosophers of artificial intelligence.

PN: So, here is the best thing you can do with Simondon today: Acknowledge that thinking of technology is technology. According to Simondon, we need to become students of technology in order to develop our thinking. You do not have to be a techno-utopian or even imagine that technology is the most important thing in the world, to understand that technical modes of objects are resources for thinking. I think Deleuze does that, though he avoids history. The most important thing Simondon does is to combine empirical history and the phenomenological history of someone like Heidegger, into the genesis of an object. He is a kind of materialist historian, let us say. Very different from both Marx and Braudel, but drawing a straight line through them.

JF: He is also trying to "liberate" technical objects from systems of politics.

PN: Yes, that is a problematic aspect of Simondon. My presentation at the Yale Simondon conference was about why Simondon never mentions the bomb. It must have been on everyone's mind. It certainly was when he was beginning to write.

$\mathrm{JF}$ : It was the technology in his time.

PN: The example of world-destroying technology. A humanity-destroying technology. A technology-destroying technology. In a sense, the bomb expresses the limit of his way of thinking about technology. Because it expresses a functionality to reduce the technical age to absolute dysfunction. There is no constructive use of a nuclear bomb. The only constructive use is to not use it.

Not using technology is an interesting issue. Simondon is not really an advocate of using technology. That is what Heidegger's argument was about: using technology. Simondon is advocating building technology, developing technology, living in the 
embrace of the tinkering, and seeing human history as in a reciprocal interaction with the development of technology. But his anthropology is very different from the usual anthropology of technology, which says that humans use technology and worries if they will end up being abused by technology in the end. Human beings are already within the technical apparatus, as part of it and also as part of its milieu, which is the bigger apparatus.

JF: It is where humans and technical objects coexist?

PN: A human is that kind of carburetor that mixes the fuel from the milieu to run the development engine. That is a very interesting idea: there is nothing mechanistic about machines for Simondon.

JF: How so? I know he speaks a lot about the automobile and the water mill?

PN: Right, but they are not automata. The object is not in its function or its purpose, it is in its genesis. Thus, these things are not merely animated by the human being, the water mill animates the human operators too-it animated them as inventors, refiners, duplicators, manufacturers, and finally as workers. This is especially the case in the domain of development. To Simondon, the inventor plays a very small role. He feels the initial constraints of the initial bad formulation of a technical object, and can - "within the obstacles set" - move things around and open a new path. This is a vision of constrained freedom. Or a freedom to manipulate certain constraints. The final product - or the initial sketch - does not matter that much however. What is important is the further work within these constraints, the going into the machine to develop its logic.

JF: So, he is rejecting the schoolbook version of development: The reason the locomotive came about, was because of a need for mobility.

PN: At first needs are given outside of any system. Obviously other needs are created by the technical system after a time anyway, right?

JF: What about aesthetics? There is an aesthetic vision somewhere in his writings.

PN: We have been talking about the technical object as having some relation to "perceived needs". Which is another way of speaking of the difference between function and functionality. It is interesting that technical objects also have to be or become information. Information for Simondon is the goal of aesthetics. What does that mean? Here is an interesting definition of information: A function or a figure that moves from a milieu in which it is familiar to a milieu in which it is foreign. So, in some sense a technical object cannot simply satisfy a need. It also has to be a relation to an outside, it has to come through a shift, it has to come and by its very 
working from afar "revise" the need. As though it could be possible for a simple need to produce an invention to fill it. We know this about technology too. We always needed to carry a computer in our pocket, but of course we never thought of it. The need did not predate the invention. Beyond being a machine that does something, a technical object contains the thought of the next need.

JF: Suddenly it was there.

PN: It came as information, it came as - one says in mathematics - an undefined variable. To a small coterie of technologists, it may have come as something familiar, though that is because they are imagining warping the current milieu, while to everyone else it comes as information. Only so long as it remains information, is it technology. The iPhone, in other words, is already no longer technology. Technology has to have this informational quality.

Let's go on with this ready example. Simondon thinks that information comes from elsewhere into a situation that is somewhat chaotic and helps to stabilize it gives it a little bit of form. It is obviously not responding to a perceived need, but coming in to re-adapt a situation, diminish a certain tension, and expose a part of the context that had been hidden. And you can see that the iPhone did that. Once stabilization is accomplished, it becomes part of the new chaos, part of a new tension, awaiting a further gizmo. There is a theory of history here in which gizmos respond to social tensions as information, as forces of re-ordering, which, if you look at this from an empirical view, does not quite explain how it is working historically. Information reconfigures the milieu but at that time it becomes part of the milieu, and insofar as there is still tension, it then takes another technology to come in and stabilize again. So the stabilizing force is only active insofar as it is information, not even yet being used, as we usually imagine technology to be, being in its use - this is my reading of Simondon.

JF: So, when he speaks of cars and, in a sense, traditional technology - in a very knowledgeable and in-depth way - he is also thinking about these types of technologies as information, at the core?

PN: Yes, absolutely. He does not talk so much about the mundane social effects of automobiles; how people could get around, how efficiently, how fast. He is not interested in that.

JF: He is interested in the parts and how they work together.

PN: And how they involve people in a process of becoming foreign to themselves. In modern philosophy there tends to be a political quality to technology - you can 
see it in Hegel: it is the slaves' interaction with tools that the master cannot have that makes the master a slave of the slave. Simondon was interested in that dynamic too, from a different perspective. Hegel of course was only interested in the use of tools-use gave power. For Simondon, again, it is not use but genesis that involves human beings in technopolitics.

JF: What does the genetic part mean, in this case?

PN: Not progress, for sure. Progress means to develop something that fits in your hand better than a stone does; it's task is to "extend capabilities." This then is a straight-ahead humanism. With progress, surprisingly, a human being is not involved in the object, and so it is not a true genetic technical process. An abstract ideal lead you to make a better widget. Participating in the fabrication of a world, which is the fabrication of new needs, is different. Marx is thinking about this too in the machinery section of Capital. He thinks not so much about the products they enable workers to make or the higher speed at which the work goes, but about how the machines remake the people. Machines make workers into machine operators and they also unmake workers as craftspeople. And they make capitalism into an efficient producer of surplus value. Industrial machines produce... a new landscape for thought and action.

JF: Does Simondon agree with Marx?

PN: He agrees that technical objects change all the relations in a milieu. We could say that technical objects are absolutely archaic-every made thing is technical. There might be clues in the history of technology that human beings have always been "homo technici", but it is not until the invention of machines that homo is subsumed into the genesis, of itself and the objects. You do not have to tinker much with a hammer. Hammers have not changed much over the millennia.

JF: If he brings any fundamental insight to philosophy, it is to stress the importance of technology in philosophical thinking from the start. Is that fair to say?

PN: Perhaps his most important contribution is to stress the radical change that technical objects make in the movement of history and thought. You can say it in another way: "everyone is an engineer". That is how Spengler would have said it. Engineers participate with things and in history in a different way-they mediate designs. In this way engineering is fundamentally different than using. Here Simondon also differs from Heidegger. Heidegger only thought about using tools, and about use as a mode of practical interpretation. Now humans have become the combustion engine's instrument for the emergence of carburetors, if we think of an 
engine as an expression of a need-in-transformation towards-an-end it cannot foresee.

JF: Simondon also seem to think about machines as organisms, influenced by ecological thinking and cybernetics. What is really to gain from describing machinery and technological systems from what we normally would think of as organic entities, in your view?

PN: Through Canguilhem Simondon's way of thinking is colored with evolutionary paint, and there certainly are analogies to be made with Darwin and later theorists. Where Simondon is very much like an evolutionary thinker, is in his word ensemble. Object, engineer, milieu-altogether form an ensemble, which is the fundamental unit of history-much like organism, environment, and niche in evolution theory. One lesson of both is that environment cannot be separated from object-Simondon stresses that the milieu is in the object, and the engineer is in the object as well. The three form a circuit that operates in a meta-technological way, each feeding the others. As dynamic as this seems, he nevertheless has a strong inclination towards balance. He likes order, he likes stability, even though he is willing to disrupt a lot of things to get there.

JF: Balance of what?

PN: $\mathrm{He}$ is not interested in the depletion of natural resources or the mystical harmony of ecosystems.

JF: He seems to be observant of - and that is probably why I spoke of aesthetics before - a certain beauty of machinery functioning - a machine doing what it should be doing.

PN: Machines in operation interest him, but the responsive, reciprocal course of their genesis that moves toward stability interests him more. Whether you are driving a pickup truck, mining rare earth metals, or coding software, the technical objects that enable you have their birth, growth, deviations, and death.

JF: Right, Simondon wants to move away from function seen as an ordering of machines to perform to our needs, and instead look at where the function is coming from and where it is heading, I suppose. Does it make sense to speak of a fulfilment of becoming?

PN: If you mean by that a following out of certain implications, some of which will open onto further implications. Contingency is the main product of building. Look at the development of the iPhone. You see how the refinements are built up from the previous stages. I think the best way to talk about it is as a movement from confusion 
to fusion. It is not as though the possibilities of the next version of the iPhone are contained in the previous version, but you can, given your competences, find a space there, and work on it in a certain way. The way you work on it is conditioned by the way you worked on the previous one, and together something fuses out of this. I talk about, in other words, constraints and possibilities that are not all actualized. Every moment is hypertelic in that regard. And that is the difference between Hegel and Simondon. For Hegel historical objects internalize difference; for Simondon, technical objects externalize difference. They are hypertelic-they fly beyond their dialectical summation.

JF: It sounds like a theory of complexity. You cannot determine it. It will play out, but we cannot say in which way.

PN: One question is where does the drive to keep tinkering come from? That is something I do not understand. Is Simondon a Nietzschean in that he thinks it comes from the passion of the tinkerer? Sometimes it seems like there is a kind of slingshot effect; one alteration leads to another, it goes through its iterations, and drags us all with it.

He does not think it is demanded of capitalism. In Simondon, there is no such thing as progress - it is a mode of existence, that can be analyzed. Capitalism depends on the myth of technological progress. Simondon shows us that there is no progress in technology. It follows a fundamentally different model of history. So, if that is the case...

JF: ... then capitalism employs a model of history that is incompatible with Simondon's way of reasoning?

PN: Capitalism is wrong. According to Simondon, capitalism builds on the false conception of technology as something related to progress. I would not say that the mood is critique, necessarily, but it would be a fundamental shift in mode of thinking. And you could develop or promote the engineer or the tinkerer's position as an alternative. But it is so easily subsumed into capital, right? The tinkerer has a little bit of freedom. If you want to use Simondon to develop a critique of technology - what would that be? Can you apply Simondon's perspective and be a critic of technology? That would be the question. And I do not have an answer to that.

Did you ever see the film by Terry Gilliam - Brazil?

JF: Brazil, yes.

PN: There is this revolutionary or at least rebellious plumber played by Robert de Niro. He is a tinkerer. He is not invested in the system. He does not make things 
better; he neither keeps order nor keeps the system going. Technical malfunctions, in a totalitarian system or in capital, exist not only to prove the need for the system, but also to discipline the people, to show them that they are submitted to the system. This renegade plumber merely patches up the mess, temporarily, without concealing the system again and the tenant's dependence on it under the pall of good function. Unofficial technologists could be Simondon's answer. Bill Gates and those sorts of people went from being unofficial technologists to really ruling the world.

JF: So, if Gates and the Hewlett Packard people would have stayed in their garages and kept on tinkering, and had not become global billionaires...

PN: Now we are talking about the movement of capital, which has become parasitic on technology. The movement of technology is another thing entirely. Sometimes they even work against each other. A line of big investors is waiting to capitalize AI, but the genesis of the object is still in process.

JF: And the capitalist explanation is that capital is making better technology.

PN: That is not the movement of technology, according to Simondon.

$\mathrm{JF}$ : That is part of the progress myth?

PN: You could say capital makes better technology for sales, but there is no such thing as "better technology". It is the process of thinking certain technological forms that the tinkerer takes on.

JF: It borders on the view of an artist. Without posing as one, perhaps.

PN: And without the fiction of that kind of freedom. The kind of freedom where you can do anything, like ex nihilo creation. Simondon wants nothing to do with that. It is the middle person, the one who can take an invention and actually make it into a form of life, bring it in line with the milieu and allow each to change the other, that is interesting for Simondon.

JF: When I read parts of Simondon's book, On the mode of existence of technical objects, I was reminded of what Heidegger is saying: Here is a block of marble and that block of marble wants to become this beautiful, perfectly balanced statue. I recognize a similar idea in Simondon, an idea of "this technology wants to become" something. Which I read as an expression of a sort of essence.

PN: Yes! I think it is best to think of it as a freedom of constraints. And constraints then give birth to other possible movements. Heidegger just does not have enough of a sense of the material of stone. But he does talk about gravity, when he talks of sculpture as opposed to, for example, frieze making. There is something in the 
material - in this case the stone - that leads towards upright, human forms, through the constraint to the new freedom, so to speak.

JF: It cannot become anything.

PN: You cannot do anything with any material. And this is not just a constraint seen in art history. You would not call it essence, but there is a physical fact that is hard to overcome. Stone sculptures stand on the ground. They have a high tension between the material and the representation that projected images for example do not.

JF: There seems to be a lot of respect, if that is the word, for materials and the dynamics between who is making stuff in Simondon's writing: a sort of "listening" to the material.

PN: That is a beautiful way to put it. An extreme example of that is a book by the Deleuzian thinker Manuel de Landa, on chemistry, Philosophical Chemistry. Genealogy of a Scientific Field (Bloomsbury, 2015). There, he argues that chemistry even goes beyond the constraints of machines, which still always were expected to "do something". Chemistry is satisfied with acting and reacting and transforming into new substances. It expresses a kind of combinatorics, that a lot of things can emerge from. You do not even know if it is going to have "functions" at all. It is really quite open and... scary.

JF: Would de Landa be an example of someone who thinks along Simondonian lines?

PN: Through Deleuze. For sure.

JF: Is there a Simondon-moment right now?

PN: If anything, we are all looking for resources these days. And Simondon is one, although a terrifically weird one. One thing Deleuze taught us - and Heidegger too - is that the unthought is more promising than the thought. This is the difference between philosophy and theory in the United States. Theory works on the unthought and philosophy on the thought. Simondon is just a trove of unthought for our current situation. But I don't think there is a renaissance of Simondonian thinking.

JF: People do not get high on Simondon, like they do on lots of other thinkers? PN: Exactly. You know why? This is a totally different topic. Deleuze has a kind of prose style that liberates people - except for the die-hard Deleuzians. Like Emerson liberated Nietzsche and German literature, Deleuze liberates people from scholarly discourse. That is the "high" you are talking about. 
JF: Which has some good parts to it.

PN: Yes. But Simondon does not give us any of those things. With him, you are forced to shift the way you think about theory. That can be painful. 


\section{Recommended Articles and Books on Simondon}

Gilbert Simondon has inspired many thinkers. We have gathered some books and articles on Simondon and Simondon-inspired thought in philosophy and critical theory that have caught our interest during the editing of this volume.

\section{Nathalie Simondon's biography of her father}

Nathalie Simondon, the daughter of Simondon, sums up her father's life in a text published on gilbert.simondon.fr, thematizing his illness and rich intellectual life. Nathalie Simondon quotes a letter from 1952, from the time when her father began to write about individuation, that was to become so prominent in his thought: "I have been working on the notion of individuality since spring. The subject seems to me to be deeply reflexive-thus philosophical". She also quotes a letter Simondon sent to Jean Hyppolite in 1954: "I have chosen the notion of individuality, and, for a year, I have been trying to create a reflexive theory of the criteria for individuality. [...] Indeed, it is necessary to grasp being before it is analyzed in terms of the individual and the milieu: the totality individual-milieu is not self-sufficient; one cannot explain the individual by the milieu nor the milieu by the individual, and one cannot reduce the one to the other." 


\section{Gilles Deleuze's review of Gilbert Simondon's dissertation (1966)}

Deleuze's 1966-review of the doctoral thesis of Simondon, L'individu et sa genese physico-biologique, translated into English by Ivan Ramirez for the magazine Pli 12 in 2001 , concentrates on his theory of individuation. Writing about principles of individuation is nothing new, Deleuze claims, but modern philosophy has avoided the issue until now. It is here, in the theory of individuation, that "the force of Gilbert Simondon's thought comes into play. He sets forth a profoundly original theory of individuation, which entails an entire philosophy." (p. 43)

\section{Bernard Stiegler, Technics and Time, 1: The Fault of Epimetheus (1994)}

As one of the most influential readers of Simondon, Bernard Stiegler seeks in Technics and Time to situate Simondon's thinking in a tradition with André Leroi-Gourhan and Bertrand Gille, arguing for technology as a misunderstood and underestimated aspect of Western philosophy with serious consequences for our understanding of man in the world. Stiegler's use of Simondon also makes clear why Heidegger's notion of technology might be inadequate in relation to time as long as it attempts to engage them separately and not together: What is time if it is not registered by techniques? How could it otherwise be known and experienced?

\section{Parrhesia-A Journal of Critical Philosophy, issue 7: Special issue on Gilbert Simondon (edited by Arne De Boever, Alex Murray, Jonathan Roffe and Ashley Woodward, 2009)}

The magazine Parrhesia has published an impressing volume of texts on Simondon, especially for those of us who do not read French and cannot take part of the rich secondary literature on Simondon in French language. This issue translates texts by Simondon and some of his most interesting interpreters, Jean-Hugues Barthélémy, Bernhard Stiegler, Paolo Virno and Igor Krtolica. In an interview with Brian Massumi, titled "Technical Mentality' Revisited: Brian Massumi on Gilbert Simondon", conducted by Arne De Boever, Alex Murray and Jon Roffe, Massumi calls for a broader approach to Simondon.

\footnotetext{
"The one thing that worries me is that there seems to be a tendency to concentrate on Simondon's theory of the technical object to the exclusion of the other aspects of this thought - physical individuation, vital individuation,
} 
and psychic individuation (synonymous for him with collective individuation). The force of Du mode d'existence des objets techniques [On the Mode of Existence of Technical Objects] cannot be fully understood in isolation from the overall theory of qualitative change - what he calls "allagmatics" - which is dedicated to understanding these modes of individuation in their relation to each other." (p. 38$)$

\title{
Muriel Combes: Gilbert Simondon and the Philosophy of the Transindividual (2012)
}

Combes's book is philosophically intriguing as well as a brilliant introduction to the philosophy of Simondon, particularly his theory of individuation. Among the many interesting themes Combes touches upon in her book is the ethics of Simondon, which she relates to his understanding of reticularity and the collective individuation referred to in the title of her book.

\begin{abstract}
"In such an ethics, the subject lives on by affirming its relative character, or more precisely, its relational character, by inscribing its acts into the network of other acts as much as it can. (...) To act ethically, for a subject, means in effect to be affirmed as a "singular point in an open infinity of relations" (...), that is, to construct a field of resonance for other acts or to prolong one's acts in a field of resonance constructed by others; it is to proceed on an enterprise of collective transformation, on the production of novelty in common, where each is transformed by carrying potential for transformation for others. This, then, is the definition of collective individuation, opening into the dimension of transindividual." (p. 65)
\end{abstract}

\section{Bruno Latour: An Inquiry into Modes of Existence (2013)}

The French thinker Bruno Latour continues his exploration of knowledge and truthconditions in this book, with a title that also plays on Simondon's famous book, $O n$ the Mode of Existence of Technical Objects (1958). The scientific institution as we know it is just one of the modes of existence (or modes of extension, according to Latour) that delivers truth today, and Latour calls for an opening up of other modes of existence. Thus, the book dives deeper into the ideas formulated in the book We Have Never Been Modern (1991), by qualifying the questioning of the universality of the ideas of modernity. 
Yuk Hui: Cosmotechnics as Cosmopolitics (eflux vol. 86, 2017) and "On the Soul of Technical Objects: Commentary on Simondon's 'Technics and Eschatology" (Theory, Culture and Society, vol. 35: 6, 2018)

In both "Cosmotechnics as Cosmopoltitics" and "On the Soul of Technical Objects" Yuk Hui uses Simondon to establish a concept of cosmotechnics, relating cosmology, moral and technology. Building on the unique understanding of culture as intertwined with technology and nature in Simondon, Hui defines cosmotechnics as "the unification of the cosmic order and moral order through technical activities" (2017). In the second article recommended, Hui writes about the concept of the soul in Simondon and relates it both to the alienation of technical objects Simondon himself is writing about, as well as to the Marxist concept of alienation. Yuk Hui has also written an updated answer to questions Simondon posed in his 1958 magnus opus: On the Mode of Existence of Technical Objects, titled On the Existence of Digital Objects (2016).

\section{Elisabeth Grosz: "Simondon and the Preindividual", chapter 5 in The Incorporeal - Ontology, Ethics, and the Limits of Materiality (2018)}

In this chapter in The Incorporeal, Elisabeth Grosz reflects upon affections in relation to Simondon's concept of collective individuation. "Anxiety", Grosz writes, is an "operation with no action, a permanent emotion that is not able to resolve affectivity" (p. 192). Anxiety arises when an individual is "cut off from an order of collective being through which it can address its anxiety and enter a new kind of relation in which it can again invent new ways of living in a world that it cannot control." It is a collective existence, Grosz writes, that "provides a 'much vaster' place, or many, by which the subject can overcome itself and enter into new relations (...)." (p. 192f). 


\section{Vocabulary}

This vocabulary is inspired by "A Short List of Gilbert Simondon's Vocabulary" on the blog Fractalontology, but for the most part based on the article and interviews in this issue of Sensorium Journal. For more concepts, see:

Fractalontology.wordpress.com.

Abstract machines: The concept "abstract machines" comes from the French philosopher Gilles Deleuze but is inspired by Simondon. Simondon does not talk of abstract machines as such, but rather about "technical essences". According to Gary Tomlinson in an interview in this issue of Sensorium Journal, abstract machines are: "A set of processes that arise immanently from an assembly of matter and energy" and: "The immanent processes that arise in the course of evolution". Abstract machines are differentiated from concrete machines, like coffee makers. Tomlinson gives examples of abstract machines from the history of evolution: Niche construction, autopoiesis and natural selection.

Hylomorphism: Hylomorphism refers to an Aristotelian model of form-matter, which Simondon criticizes. The term comes from the Greek hylo meaning 'matter' and morphe meaning 'form'. It represents a worldview where form is thought of as more important than matter: where form is active, and matter is passive. Instead of hylomorphism, Simondon argues for a model of the world beyond the abstract 
construction of form-matter, characterized by "metastability", "information" and "potential energy".

Hypertele: According to Paul North in this issue of Sensorium Journal, hypertele means that "the functionality of a technical object goes well beyond its 'function'. Which is to say, a particular use of a certain technical object does not exhaust its potential application."

Individuation: Stages of being. A fundamental idea in Simondon's thinking is that individuals are not given but are shaped into being through a process of individuation. Originating in a super saturation of being, from which individuals, objects and milieus arise, different stages in being (stages of individuation, such as pre-individual, individual, trans-individual) are reached by resolving potential energy at each stage. Steven Shapiro has in a note suggested that individuation is "quite similar" to autopoiesis as defined by Varela and Maturana.*

Information: A term Simondon prefers instead of "form". The concept of information is connected to Simondon's idea of perception: when we perceive, we perceive information, not form. We use information to orient ourselves in a world, and information is only perceivable in a system. In this issue of Sensorium Journal, Paul North defines information as: "A function or a figure that moves from a milieu in which it is familiar to a milieu in which it is foreign."

Milieu: A concept Simondon has borrowed from the French philosopher Georges Canguilhem. The milieu is not something distinct from the object/individual and is neither preceeding the individual nor created by it. According to North in this issue, " $[\mathrm{t}]$ he milieu includes everything from the kind of life practices of the technicians to the tools available in the lab."

Metastability: A metastable situation is characterized by non-stable high energy, or a false equilibrium, according to Muriel Combes in Gilbert Simondon and the Philosophy of the Transindividual, 2011, p. 11. For example, a pre-individual being is in a metastable state.

\footnotetext{
*Steven Shapiro: "Simondon on individuation", published January 16, 2006. URL: http://www.shaviro.com/Blog/?p=471, retrieved February 17, 2021.
} 
Ontogenesis: An ontology that rejects dualisms and substances, and focuses on the ongoing genesis of being, instead of the categories of being.

Perception: An active integration of information, based on detecting and formulating problems and finding solutions. Perception is an ontogenetic process, and form is invented in the process, not revealed or recognized. In an unpublished talk mentioned in Gary Tomlinson's interview, Simondon likens the process of perception in organisms to the process of modulation in machines. Fractalontology.org defines perception as "a mode of engaging with the world so as to retrieve useful information about its orientation."

Potential energy: Necessary for individuation to take place. Potential energy is energy that exists in a system but is not structured. When there is potential energy, there is an incompatibility. Potential energy requires system change in order to be structured or actualized. The process of individuation actualizes potential energy.

Pre-individuality: A state of being that is metastable, according to Muriel Combes in her book Gilbert Simondon and the Philosophy of the Transindividual (2011, p. 11). Thus, it refers to a stage of being which involves incompatibilities that needs to be resolved.

Problems: Gilles Deleuze was particularly interested in the idea of problems in Simondon's thought, as shown in the article by Stefano Daechsel in this issue of Sensorium Journal. As Daechsel stresses, according to Deleuze, Simondon sees problems as "ontologically independent realities that are objective, but not recognizable in the same way as 'objects of sense experience'". They do not disappear once they are solved. "Problems are systems of 'differential relations between genetic elements' that can be expressed in a number of solutions".

Technical essences: Essence arises in abstract machines, or in assemblages. Essence is not a transcendental concept, but, as Paul North puts it in this issue of Sensorium Journal, "just the generative trajectory of a certain technical object - there is no essence beyond the particular historical life of the object." According to John Durham Peters, also in this issue, essences in Simondon's thinking are historical or provisional, not eternal and unchangeable. Essences can also be defined, as Gary 
Tomlinson does, as "immanent things within arrays of materials with flows of energy running through them."

Trans-individual: A collective stage of being, that in some way remembers the previous stages (pre-individual, individual), and therefore can nourish from them. 


\title{
Review: Cybernetics: The Macy Conferences Johan Fredrikzon
}

\author{
Claus Pias (ed.), Cybernetics: The Macy Conferences 1946-1953. The Complete \\ Transactions (Diaphanes, 2016)
}

The historical and theoretical significance of cybernetics makes itself apparent in several domains. In addition to being the soil in which cognitive and behavioral sciences as well as computer science and ecology must seek their modern roots, cybernetic lines of thought continue to inform plenty of posthuman efforts to decenter traditional conceptions of man and his consciousness as requirements for agency, creativity and meaning.

To the fields of research that cannot neglect a cybernetic influence, we must also count digital humanities and media theory. From one of the strongholds of the socalled German school of media theory, Leuphana Universität in Lüneburg (others include Bochum, Berlin and Weimar), professor of history and epistemology of media Claus Pias has compiled and edited the proceedings from cybernetics' most noted, frequently mentioned albeit largely underestimated or misunderstood gathering: the Macy Conferences that took place between 1946-1953. Having been published in 2003/2004 in German, they are now available for an English audience in one, thick, black 700-page volume.

The proceedings of the conferences have been edited and published before. Heinz von Foerster, himself a prominent Macy attendee and distinguished cybernetician, edited the output of the conferences in the order in which they had 
taken place (as of $195^{\circ}$ with the assistance of Margaret Mead and Hans Lukas Teuber). The greatest value of the new publication under the editorship of Pias resides in its being a complete reference to what was actually presented, disputed and discussed at the series of meetings. Under Pias' careful editing, it's simple to find out who said what at which meeting (even who sat where, which the participants themselves, in a cybernetic bend, took as information worthy of note).

The impressive scope and range of topics dealt with at the conferences makes the volume relevant for many disciplines that need to investigate a less known or misrecognized part of their $20^{\text {th }}$ century past. The Macy Conferences take on, to mention a few subjects, psychology and perception, neurosis, the quantum mechanics of memory, the digital components of the central nervous system, the mechanisms of recall, the intelligibility of distorted speech, the meaning of language, the role of communication in problem solving, hypnosis, the communication of animals, noise, homeostasis as a concept, the feedback of emotions and the learning abilities of octopi.

This almost Borgesian list of items originates from the basic conviction that objects, processes and behaviors whose characteristics might seem distant from one another, can - indeed: should - be studied as being arranged and operating according to a common set of principles. By combining the insights from several fields of knowledge, the driving forces of the conferences sought to establish cybernetics as a new, universal science, positioning machines and organisms alike as systems operating to reach goals by using negative feedback mechanisms as their main control instrument.

The optimism and confidence behind such an ambition brings an intellectual force but also a flexibility of thought to the gatherings that in itself is inspiring even if the reader neither agrees with the premises nor the results. Even though the similarities seem convincing, coming from luminaries such as Norbert Wiener, Arturo Rosenbleuth and John von Neumann, between self-regulating weapons systems and brains, sea vessels and animals, the movements in a cat catching a rat and a baseball player hitting a ball, the Macy effort has seen some well-deserved criticism. ${ }^{*}$

In his helpful introduction, Pias positions his editorial effort against the influential work Constructing a Social Science for Postwar America: The Cybernetics Group,

\footnotetext{
*E.g. Peter Galison, "Ontology of the Enemy: Norbert Wiener and the Cybernetic Vision", Critical Inquiry, Vol. 21, No. 1 (Autumn 1994); N. Katherine Hayles, How We Became Posthuman: Virtual Bodies in Cybernetics, Literature, and Informatics (1999).
} 
1946-1953 (1993) by Steve Joshua Heims. Where Heims gives an informative account of the cybernetic uptake in social sciences, he is ultimately very critical of how, in his view, cybernetics distorted and oversimplified areas where it lacked the tools to make a real and lasting contribution. Instead of taking issue with the detailed arguments in Heims' reading, Pias seeks to turn our attention to other aspects of the founding years of cybernetics: the ontological goals and, primarily, the groundbreaking reasoning regarding the status of the ideas of the analog/digital, that has engaged so much of contemporary media theory in the last couple of decades.

To this end, Pias highlights three parts of what he terms "a set of models" that make up the backbone of cybernetic thinking: 1) logical calculus (by Pitts and McCulloch), 2) information theory (by Shannon), and 3) behavioral theories (by Wiener, Bigelow and Rosenbleuth). These three components - a universal theory of digital machines, a stochastic theory of the symbolic, and a non-deterministic yet teleologic theory of feedback - were, according to Pias, combined into a singular theory purportedly applicable to living organisms as well as to machines, to economic as well as psychological processes, to sociological as well as aesthetic phenomena.

Moreover, and this is the most important claim of the volume's editor, all these components rest on a common condition: digitality. Hence, for Pias, they presume a digital basis of operation. Only then could cybernetic epistemology enter a productive mode.

This brings Pias to the interesting claim that cyberneticians in the $1940 \mathrm{~s}$ preceded the French philosopher Michel Foucault in his critique of the sciences of man. At the Macy conferences, the accepted conceptions of man, mind and knowledge were criticized, and efforts were made to find alternative explanations of what constituted these. Before Foucault saw the face of man disappearing in the sand at the end of The Order of Things (1970 [1966]), the Macy Conferences placed him next to a thermometer.

Imagining man and world as, basically, digital machines, Pias notes, entailed the strategic forgetting of the "in-between-ness" of things, i.e. the analog qualities, which it to say, the material dimension of the world. ${ }^{*}$ As a consequence, cybernetics eventually came to be largely reduced to "informatics" or computer science as a field seeking only to improve machines and design better programs instead of engaging

\footnotetext{
* For an in-depth discussion of this, see: Claus Pias, "Analog, digital, and the cybernetic illusion", Kybernetes, Vol. 34, No. 3/4, pp. 543-550 (2005).
} 
in ontological and epistemological combats. It is obvious that Pias laments this development of cybernetics into a kind of Kuhnian "normal science" and part of his work in making the proceedings from the meetings widely available originates from his appreciation of an emerging science that was willing to take on the most fundamental questions of knowledge.

As Pias also points out, cybernetics has had far-reaching implications for the simulation of complex processes, not least in climate science. It lies, too, at the center of Actor-Network Theory, even if it is rarely articulated, and has, more recently, brought Erich Hörl to a reading of the 20 th century as the cyberneticization of society in his call for an understanding of contemporary thought from the perspective of a general ecology..$^{\dagger}$

Whether or not we choose to agree with Claus Pias' positioning of cybernetics as the foundational attempt to seriously think about "the digital", readers from many disciplines and vocations will benefit from being able to reference the complete Macy Conferences conveniently in one volume.

\footnotetext{
* Other scholars who have been returning to the more inspirational and ambitious, but not necessarily less troubling, past of cybernetics include Andrew Pickering, The Cybernetic Brain: Sketches of Another Future (2010); Bernard Dionysius Geoghegan, "From Information Theory to French Theory: Jakobson, Lévi-Strauss, and the Cybernetic Apparatus", Critical Inquiry, Vol. 38, No. 1 (Autumn 2011), pp. 96-126; Eden Medina, Cybernetic Revolutionaries: Technology and Politics in Allende's Chile (2011); Daniel Belgrad, The Culture of Feedback: Ecological Thinking in Seventies America (2019).

† Erich Hörl, "A Thousand Ecologies: The Process of Cyberneticization and General Ecology", Diedrich Diederichsen and Anselm Franke (red.), The Whole Earth. California and the Disappearance of the Outside. Berlin: Sternberg Press, (2013), pp. 121-130. translated from the German by Jeffrey Kirkwood, James Burton, and Maria Vlotides.
} 


\section{Recension: Understanding Media Ecology Per Israelson}

Dennis D. Cali, Mapping Media Ecology: Introduction to the Field (Peter Lang, 2017)

Lance Strate, Media Ecology: An Approach to Understanding the Human Condition (Peter Lang, 2017)

\section{Mediet är budskapet}

Marshall McLuhans mediestudier och det mediebegrepp han lanserar i ett antal undersökningar under framför allt 1960- och 70-talen har haft stort inflytande på samtida medieforskning. Om inte annat är hans teoretiseringar av medier som utvidgningar av den mänskliga sinnesapparaten särskilt relevanta - och närmast självklara - i den postdigitala epokens uppkopplade och datoriserade tillvaro. Det är uppenbart inte deras innehåll, utan de digitala mediesystemens totala och omslutande närvaro som påverkar och har inflytande över oss. Vad som kommuniceras är underordnat systemets tvång att kommunicera, om så bara metadata om sömncykler och digitala rörelsemönster. Mediet är utan tvekan budskapet.

Det centrala i McLuhans mediebegrepp är att kommunikationens fysiska organisation är lika viktig som dess innehåll, om inte viktigare. Denna tekniska och materiella sensibilitet, som betonar praktik, process och förkroppsligande aspekter hos meningsproduktionen, är inte unik för McLuhan, även om han (sannolikt) är den som först talar om detta epistemologiska och ontologiska skifte mellan figur och 
bakgrund i termer av media. McLuhan aktualiserar mediebegreppets klassiska betydelser av "mellanläge" och "relation" och hävdar att mediet inte opererar mellan sändare och mottagare, utan mellan medier. Ett mediums innehåll är ett annat medium, för vilket mediet utgör en materiell och strukturell omgivning och möjliggörande förutsättning. Ett mediums utsida är med andra ord ett annat mediums insida.

Dels innebär detta den ganska triviala poängen att medier innehåller andra medier som $i$ historiskt situerade processer närmast tycks inbegripa ett slags evolutionär kausalitet: tryck innehåller skrift, skrift innehåller tal, television innehåller film och radio, datamaskinen innehåller skrivmaskinen, osv. Jay Bolter och Richard Grusin beskriver denna process i termer av remediering i Remediation: Understanding New Media (1999). Men McLuhans mediebegrepp innebär också att det upprättas en konstituerande relation mellan medium (som innehåll) och medium (som omgivning). Och denna relation inbegriper alltid den mänskliga sinnesapparaten, som med andra ord bestäms och organiseras av mediets relationer. Mediet som miljö och teknisk infrastruktur blir här en formerande aktör och utverkar ett inflytande över den mänskliga konstitutionen.

\section{Medieekologi}

Denna aspekt av McLuhans mediebegrepp är vägledande för det fält inom mediestudier som har kommit att kallas medieekologi. Medieekologin fokuserar ett av kommunikationens mest fundamentala problem, nämligen frågan hur relationen mellan ett medium och en omgivning organiseras. Det vill säga: Hur formas en erfarenhet av en medial omgivning och infrastruktur? Om medier fungerar som omvärldsformerande infrastrukturer och miljöer - eller "environments" som McLuhan säger - blir förstås relationen mellan medier och subjekt av avgörande betydelse. Något förenklat kan vi säga att det handlar om att förstå och teoretisera den kausala relationen mellan ett system och en omgivning, mellan medium, miljö och människa, men utan att reducera erfarenheten till en effekt av denna mediala omgivning. Hur kan medier ha inflytande över människans sinnliga erfarenhetsproduktion - kort sagt, över mänsklig kreativitet - utan att vi hemfaller åt teknikdeterminism?

Svaret på denna fråga splittrar idag medieekologin i två grupperingar, som åtminstone tentativt kan delas upp i en humanistisk och en posthumanistisk skola. Gemensamt för dessa två skolor är inspirationen från McLuhan, men i övrigt är bris- 
ten på kommunikation dem emellan förbluffande påtaglig. Den posthumanistiska medieekologin, som jag själv ansluter mig till i min forskning, formuleras i stor utsträckning utifrån en cybernetisk och processfilosofisk horisont, med en nymaterialistisk förståelse av aktörskap och agens. I denna version av medieekologi, som vi finner hos till exempel Matthew Fuller, Jussi Parikka, N. Katherine Hayles och Levi Bryant, kan tekniska system och icke-mänskliga organismer och organisationer tillmätas ett kvalificerat aktörskap som del av ett ekologiskt assemblage. Möjligen är det att gå för långt att tala om en posthumanistisk medieekologisk skola, snarare handlar det om en uppsättning gemensamma utgångspunkter och en orientering mot en systemteoretisk och ekologisk begreppslighet. Ett sätt att beskriva detta aktörskap är genom Jane Bennetts teoretisering av distribuerad agens, enligt vilken mediet då skulle operera med en cybernetisk och systemteoretisk återkoppling mellan medium och omgivning (även om Bennett talar om system, och inte om medier).

Medieekologins humanistiska läger har emellertid en tydligare organisation, med just drag av skolbildning, och växer fram dels kring McLuhans krets av kulturoch medieorienterade forskare vid Toronto University under 1960- och 70-talen, dels kring den forskarskola inom medieekologi Neil Postman grundar vid New York University. Utifrån denna miljö bildades 1998 The Media Ecology Association (MEA), som sedan 2000 håller årliga konferenser i medieekologi. Organisationen ger även ut tidskriften Explorations in Media Ecology, vars titel anspelar på den stilbildande tidskriften Explorations, där stora delar av McLuhans och Torontokretsens mediestudier presenterades och undersöktes.

Skriftserien "Understanding Media Ecology" är knuten till denna gruppering, genom seriens redaktör Lance Strate - en av Postmans doktorander och tillika medgrundare av MEA. Två av de inledande titlarna i "Understanding Media Ecology" Mapping Media Ecology: Introduction to the Field av Dennis D. Cali och Lance Strates Media Ecology: An Approach to Understanding the Human Condition, båda från 2017 har också den uttalade ambitionen att etablera en medieekologisk disciplinhistoria. Intressant, eller kanske snarare frapperande nog, sker detta helt utan att överhuvudtaget nämna representanter för den posthumanistiska riktningen, trots att båda böcker alltså utkommer tio år efter Matthew Fullers Media Ecologies: Materialist Energies in Art and Technoculture, vars titel om inte annat borde ha förlänat den ett omnämnande. 
Det finns uppenbart en ambition att skriva bort den posthumanistiska medieekologin ur disciplinhistorien, och den främsta anledningen tycks vara en ovilja att tänka teknisk och materiell (och icke-mänsklig) agens som annat än teknikdeterministisk. Det vill säga, trots att både Cali och Strate diskuterar medier som formerande omgivningar, vill de inte kännas vid att dessa omgivningar kan ha ett inflytande som i slutändan inte tillskrivs ett mänskligt aktörskap. Kreativitet är hos Cali och Strate alltid en fråga om mänsklig vilja och kan inte uppstå inom ett tekniskt eller medialt system. Medier och teknologier utgör här alltid en begränsning av det ursprungligt och egentligt mänskliga.

På flera sätt är det olyckligt med detta slags tydliga revirtänkande, dels för att det medför ett osynliggörande av stora delar av den teknik- och medieforskning som i linje med McLuhan öppnar för en mer nyanserad förståelse av teknisk agens, dels för att oviljan att teoretisera teknisk agens som annat än ovälkommet inflytande riskerar att göra oss blinda för övervakningskapitalismens fångst- och kontrollapparater. Frågan är då, i vilken utsträckning den humanistiska medieekologin som disciplin - och den humanistiska begreppslighet Strate och Cali ramar in sina ekologiska resonemang med - kan vara behjälplig om vi kritiskt vill granska en samtid i vilken digitala medier opererar som just det slags omslutande och omvärldsformande miljöer som McLuhans ekologiska mediebegrepp förutskickar.

\section{Den humanistiska medieekologin: att återta människan}

Inledningsvis presenterar Cali och Strate varsin förhållandevis öppen definition av medieekologi, där studiet av medier i termer av omgivningar och miljöer ("environments") utpekas som disciplinens kärna. Denna förståelse av media återfinns - vilket också Cali påpekar - i McLuhans Understanding Media (1964) och utgör det centrala temat i den experimentella boken The Medium is the Massage (1967, utgiven tillsammans med Quentin Fiore). I The Medium is the Massage hävdas det, inte helt okontroversiellt, att "any understanding of social and cultural change is impossible without a knowledge of the way media work as environments". En mer systematisk och metodologisk genomgång och teoretisering av en medieekologisk begreppslighet återfinns dock inte hos McLuhan, vilket huvudsakligen handlar om att McLuhan i hög utsträckning gör medieekologi, snarare än teoretiserar den.

Strate påpekar följaktligen att även om McLuhan uppvisar en ekologisk förståelse av medier, där miljöer och omgivningar används som metaforer - metaforer som också omsätts i framställningen - så är det först hos Neil Postman dessa två begrepp 
explicit kopplas till varandra. I en föreläsning för den amerikanska sammanslutningen National Council of Teachers of English, 29 november 1968 (publiccerad 1970), argumenterar Postman för behovet av en ny förståelse av media, i linje med McLuhans mediebegrepp, som inte begränsas till den moderna skriftkulturens kommunikationsbegrepp och vidhängande litterära kategorier, utan också beräknar kommunikationens materiella och affektiva inverkan på ett vidare spektrum i den sinnliga och konceptuella konstitutionen. Medieekologi som verksamhetsform och forskningspraktik syftar, enligt Postman, till att presentera denna förståelse. I sin mest koncisa form definierar han fältet på följande vis: "Media ecology is the study of media as environments".

En omgivning eller miljö ("environment") är för Postman ett "komplext signalsystem" som strukturerar den mänskliga perceptionsapparaten och som med andra ord formar sättet människan upplever och tänker. Här är Postman, menar Strate, inspirerad av Norbert Wieners cybernetik, liksom av Shannon och Weavers informationsteori, och dess vidareutveckling inom systemteori, särskilt genom Gregory Batesons ekologiska arbeten. Det finns med andra ord en tydlig cybernetisk och systemteoretisk grund i Postmans definition av medieekologi. Strate påpekar vidare att Postmans definition inte bara inbegriper att medier ska förstås som strukturerande omgivningar, utan också - även om Postman inte utforskar detta - att varje strukturerande omgivning och miljö kan förstås som ett medium. Hur denna strukturerande organisation hos mediet värderas i förhållande till det mänskliga är som sagt en kärnfråga för medieekologin, och det är tydligt att även om både Strate och Cali diskuterar mediers inflytande och formerande kraft över samhälle och kultur, är de alltså noga med att dra en gräns mot teknisk agens och vad de uppfattar som enkelriktad teknikdeterminism.

Till viss del är det just mot teknikdeterminism Strates och Calis medieekologi formeras, vilket innebär att även om McLuhan är en central tänkare, blir också hans många öppningar mot en teknisk agens problematiska och något som måste korrigeras eller åtminstone modifieras. På denna punkt presenterar Cali och Strate ett antal olika förhållningssätt, från mjuk determinism till nyanserande historiseringar och generella epokinramningar, där teknologier tillskrivs agens inom ramen för en kulturell och humanistisk organisation och, så att säga, underordnas ett primärt och övergripande mänskligt aktörskap.

Hos Postman är det tydligt att det är människans agerande som på olika sätt skapar de miljöer som utverkar inflytande. Själva utgångspunkten för hans tolkning 
av McLuhans mediebegrepp är att människan skapar (och också gör) de medier som skapar henne. Strates ambition att förbehållslöst sondera det mänskliga tillståndet som undertiteln på hans studie markerar - lämnar möjligen visst utrymme för en kvalificerad icke-mänsklig agens, medan Cali däremot kraftfullt inskärper att hans överblick av disciplinen syftar till att just "återta" människan som aktör:

With this book, I want to lift the human agent out of the cyborg human-technology conceptualization and to locate the human agent as front and center. I also want to reclaim the human agent, in that location, as principally an intersubjective being, working out his or her existence first and foremost intermingled and engaged with other intersubjective beings, technology, and other tools functioning in service of or working against that primary operation. $\mathrm{Hu}-$ man beings use technology the way we use the natural environment, but that does not make us techno-beings. People ultimately have the choice to put technology to their own purpose; they are not hopelessly bound to every technology that taunts or titillates. (xvii)

Det är visserligen relationer mellan människor och medier och människan som en intersubjektiv varelse Cali undersöker, men det sker utifrån en enhetlig och autonomiserad identitet där människan alltså inte är, som Cali säger, en teknisk varelse. Här blir det tydligt att den skola Cali och Strate företräder, och vars disciplinhistoria de också etablerar, är just Postmans medieekologi.

\section{Neil Postmans moraliska medieekologi}

I föreläsningen "The Humanism of Media Ecology", från den första MEA-konferensen 2000 (utgiven 2006), är Neil Postman tydlig med vilken inramning av medieekologin som han förespråkar: "From the beginning, we were a group of moralists" (63). Postmans utgångspunkt är om inte nödvändigtvis antropocentrisk, så i alla fall logocentrisk (och därmed ur hans perspektiv också antropocentrisk, eftersom han inte kan tänka sig ett icke-mänskligt språk). Som han konstaterar i stridsskriften Amusing Ourselves to Death (1984) - i vilken han argumenterar för att den västerländska 1980-tals människan lever under självpåtagen kontroll och reglering i något som liknar Aldous Huxleys soma-bedövade samhällsdystopi - så är språket och det talade ordet, "vårt primära och oumbärliga medium", som "gör oss till människor, bevarar oss mänskliga och bestämmer i själva verket vad det är att vara människa".

Denna logocentrism hos Postman bestämmer också hans förståelse av media, och speglas i hans modifiering av McLuhans mediebegrepp: Mediets budskap, dess 
omkonfigurering av sinnesapparatens omvärldsformering, måste filtreras genom en språklig ordning och opererar därmed som en metafor på ett symboliskt plan. Mediet modifierar den mänskliga perceptionen, men gör det alltid i relation till en redan befintlig perception, en perception som är bestämd av språket, det talade språket, men också i stor utsträckning den kritiska distans och dialog som möjliggörs genom skriften. Det är med andra ord den upplysta och autonoma logocentriska människan, och tillika rationaliteten, som Postmans moraliska medieekologi omfattar. Och för att ytterligare precisera denna tämligen klassiska liberala humanism, föreslår han i sin föreläsning fyra vägledande frågor för en medieekologisk undersökning:

1. I vilken utsträckning bidrar ett medium till användning och utveckling av rationellt tänkande?

2. I vilken utsträckning bidrar ett medium till utvecklingen av demokratiska processer?

3. I vilken utsträckning ger nya media tillgång till meningsfull information?

4. I vilken utsträckning förhöjer eller förminskar nya media vår moraliska känsla och kapacitet för godhet?

Den medieekologi som Strate och Cali företräder orienterar sig efter Postmans moraliska kompass. Det är därför ganska anmärkningsvärt att Cali i sin kartläggning av fältet inte diskuterar Postman i någon vidare utsträckning. Postmans humanistiska förståelse av enkelriktad teknikdeterminism utgör snarare den självklara och outsagda utgångspunkten för resonemanget, och om han överhuvudtaget berörs placeras han i samma tradition som Jacques Ellul och Lewis Mumford, som ges betydligt mer utrymme i framställningen. Den förstnämnde utpekas till och med av Cali, vid sidan av McLuhan och Walter Ong, som en av medieekologins "tre portalfigurer".

Genomgående är Calis presentation annars pragmatiskt strukturerad och pedagogiskt orienterad. Genom att redogöra för ett antal olika strömningar inom språk, kultur- och mediestudier under 1900-talet skapas ett slags kanon för disciplinen, huvudsakligen med fokus på enskilda forskare, vars arbeten nödvändigtvis inte behöver beröra varandra, men har tydliga teoretiska och metodologiska affiniteter. Presentationerna sker i förhållandevis korta sammanfattningar av centrala begrepp och förutom i de mer utförligare personporträtten av de tre portalfigurerna, är framställningen sorterad i tematiska kluster. Till varje portalfigur och tematiskt kluster har Cali avslutningsvis fogat en samling heuristiska tillvägagångssätt, som på ett 
sympatiskt vis utpekar potentiella användningsområden för respektive forskare, och på så vis arbetar i riktning mot en medieekologisk metod. Mapping Media Ecology utgör härvidlag en kartläggning av fältet och samtidigt ett slags verktygslåda med ett antal konkreta redskap avsedda för praktiska och metodologiska tillämpningar av teoretiska begrepp.

\section{Det mänskliga medvetandet}

Tidigt i framställningen slår Cali fast att medieekologins mest centrala tema är det mänskliga medvetandet, och särskilt hur medvetandet struktureras och påverkas av medieteknologier. Denna fråga undersöks bland annat inom det fält av kulturforskning som på engelska kallas "Bias Studies" och som behandlar vilka världsbilder teknologier underlättar och underbygger. Här lyfts inflytandet från Harold Innis kulturhistoriska arbeten, som tillskriver mediers materiella möjliggöranden en effekt på det kulturella och politiska området. Särskilt Innis uppdelning i tidsbindande och rumsbindande medier - som att exempelvis arkitektur kommunicerar över tid medan papper och inte minst elektriska medier kommunicerar över rumsliga avstånd pekar mot en ekologisk förståelse av hur samhällen uppkommer och organiseras genom återkoppling till teknologiska infrastrukturer. Teknologier - och medier - tenderar med andra ord enligt Innis att upprätta förutsättningar för teknologi- och mediespecifika subjektiviteter. Utifrån Calis genomgång utgör dessa förutsättningar ett hot mot en egentlig mänsklig subjektivitet, och partiskhet studeras för att identifiera i vilken omfattning och på vilka sätt teknologier inkräktar på denna ursprungliga mänsklighet.

En liknande hållning i förhållande till medieteknologiers organisering av medvetandet finns inom teknikstudier och skrift- och muntlighetsstudier. Det sistnämnda fältet utgör enligt Cali en av medieekologins grunder och vid sidan av portalfiguren Ong, som ges ett eget kapitel, framhålls särskilt Elisabeth Eisensteins undersökningar av tryckets betydelse för framväxten av en modern sensibilitet. Skrift- och muntlighetstudier inringar just språket som den ursprungliga mediala miljön, den ursprungliga strukturerande omgivning som Postman (och många med honom) hänför till det essentiellt mänskliga. Även de teknikstudier som åberopas, med portalfiguren Jacques Ellul i spetsen, blir i Calis kartläggning huvudsakligen en fråga om kritiska teoretiseringar av de tekniska systemens begräsningar av det mänskliga, i termer av automation, effektivitet och alienering. 
I detta sammanhang utgör Lewis Mumfords monumentala Technics and Civilization (1934) delvis ett problem för Cali. Med sin analys av megamaskinens tekno-evolution utpekar Mumford en stundande dynamisk balans inom den moderna samhällsordningen organiserad i vad han talar om som en "neoteknisk" och "post-marxistisk kommunism". Även om Mumford kritiskt sonderar de tekniska systemens inflytande över historien menar han samtidigt att den enda vägen att uppnå detta ekologisk-utopiska tillstånd utgörs av att människan på allvar assimilerar maskinen. Mumford tycks med andra ord föregripa och förespråka ett slags posthumanistisk cyborg-hybriditet. Utifrån Calis horisont blir detta emellertid till en fråga om att återta ett ursprungligt mänskligt aktörskap, som bemästrar de tekniska system som organiserar oss. Assimilationen av maskinen syftar till att organisera denna under det mänskliga, bortom maskinens inflytande. Här, liksom på andra håll i framställningen, blir det med andra ord tydligt att Cali tonar ner inslag av teknisk agens hos de forskare han inkluderar i sin kartläggning av medieekologins kanon. Det är synd, inte minst för att det finns inslag i till exempel Mumfords förståelse av hybriditet som kan diskuteras i nymaterialistiska termer, utan att det för den delen behöver handla om teknikdeterminism.

Postmans logocentriska inramning blir särskilt framträdande genom Calis utpekande av semantik och språkstudier som centrala för medieekologin. Tyngdpunkten ligger på holistiska språkteorier. I Alfred Korzybskis (i högsta grad antropocentriska) generella semantik finner Cali till exempel ett samspel mellan tid, det mänskliga nervsystemet och den psykiska och fysiska miljön, som pekar mot en ekologisk förståelse av språk. Även Susanne Langers holistiska syn på symboliskt meningsskapande och relationen mellan tecken och symbol ges av Cali en ekologisk inramning, liksom den kontroversiella Sapir-Whorf hypotesen, som utpekar en närmast radikal relationell och kontextuell förståelse av språkets koppling till kognition och perception. Här antyds återigen en icke-linjär kausalitet som ligger nära Jacob von Uexkülls umwelt-teori, och dess vidareutveckling inom biosemiotiken. Denna potentiellt posthumanistiska inriktning utvecklas dock inte. Precis som överlag, vägleds Calis kartläggning av ambitionen att hänföra all form av kvalificerad agens till ett mänskligt aktörskap. Som han konstaterar redan i sin inledning - viljan att "återta" människan som aktör. 


\section{McLuhan, teknisk agens och teknikdeterminism}

Underbetoningen av en distribuerad förståelse av agens blir även tydlig i genomgången av McLuhan. Cali påpekar att McLuhans tidiga The Mechanical Bride (1951) uppvisar en teoretiker som är betydligt mer kritisk och moraliserande i sin inställning till populära medier och teknologier, vars inflytande till viss del ses som ett inkräktande på en mer ursprunglig mänsklighet. Hos den tidiga McLuhan kan skönjas en tydligare sympati för Postmans humanistiska orientering, menar Cali. Möjligen ligger samma motiv bakom den relativt utförliga genomgången av McLuhans katolska arv, där kopplingen till ett skolastiskt tänkande, och inte minst Thomas av Aquinos dialektik, lyfts som inspiration till McLuhans "medielagar". Här understryks också inflytandet från Ongs muntlighetsstudier, särskilt i McLuhans undersökning av tryckkulturen i The Gutenberg Galaxy (1962). Cali gör också en poäng av att Ong var McLuhans doktorand.

I Calis medieekologi anpassas McLuhan efter Postmans agenda och de mer teknofila och potentiellt posthumanistiska inslagen i hans tänkande tonas ned. Det finns också en tydlig skepsis gentemot McLuhans induktiva, poetiska och närmast immanenta sätt att skriva och bedriva undervisning och forskning, tydligast exemplifierat i dragningen mot den parataktiska och paradoxala formuleringen. Samtidigt lyfter Cali just dessa komprimerade formuleringar - i stil med "the medium is the message" - som ett slags redskap, vars omkastning av relationen mellan figur och bakgrund gör att de fungerar som en form av minimala teorimaskiner. McLuhan talar också om dessa formuleringar som undersökningsredskap, som "sonder" ("probes"). Här utpekar Cali en relationell kausalitet som till viss del kan tyckas ifrågasätta en klassisk humanistisk ordning. Och eftersom det också är just dessa, det vill säga McLuhans sonder och verbala teorimaskiner, som Cali utpekar som centrala för en medieekologisk metod, förefaller det ändå som om den humanistiska medieekologin här delvis öppnar för orsakssamband som varken följer en mänsklig telos eller mekanistisk kausalitet. Det vill säga, här öppnas för ett distribuerat aktörskap. Och frågan blir då i vilken utsträckning det är möjligt att hålla fast vid en modern humanistisk begreppslighet - ett autonomt objektsbegrepp till exempel - och samtidigt tillerkänna samma objekt en ekologisk, rekursiv kausalitet.

Likväl framhåller Cali människan som en i grunden icke-teknisk varelse. Möten mellan medier som enligt McLuhan kan verka lösgörande och kreativt, godtas ur detta perspektiv endast så länge en balans upprättas i vilken det mänskliga subjektets ursprungliga (och enligt Postman språkligt strukturerade) organisation respekteras. 
En humanistisk medieekologisk metod syftar till att diagnosticera vilka sinnligheter och erfarenhetsvärldar ett medium möjliggör. Processen är moraliserande, som Postman säger. Diagnosen ställs mot en moralisk känsla som visserligen både kan förhöjas och förminskas genom nya medier, men som likväl alltid föregår mötet med en medial omvärld. Det egentligt mänskliga består med andra ord av en ursprunglig medial förlängning, nämligen den språkliga.

\section{Lance Strates (nästan post-)humanistiska medieekologi}

Lance Strate utgår i sin genomgång av medieekologin från samma discipliner och forskningstraditioner som Cali och han diskuterar mer eller mindre samma fält och forskare. Här finns emellertid en tydligare klassificering av Postman som en uttryckligen humanistisk tänkare vars studier av medier utgår från en normativ och i vissa fall moraliserande position. Strate är mer villig att diskutera de teknofila och ickemoraliserande inslagen hos exempelvis McLuhan. Han genomför också en mer utförlig undersökning av cybernetikens och informationsteorins betydelse för förståelsen av medieekologier och mediebegreppet. Gregory Batesons ekologiska arbeten ägnas viss uppmärksamhet och Strate nämner kortfattat materiellt orienterade medie- och kommunikationsstudier, som Friedrich Kittlers. Vid flera tillfällen i sin framställning öppnar han för en mer nyanserad förståelse av icke-mänskliga aktörer.

Strate opererar med en systemteoretiskt influerad teoretisering av det mänskliga tillståndet, som han menar utgörs av återkopplingar mellan symboliska, teknologiska och bio-fysiska miljöer och omgivningar. Att se natur som en polär motpart till teknologi och kultur, eller för den delen medvetande, är utifrån en ekologisk systemteori en missuppfattning - och här hänvisar Strate framför allt till Batesons medvetandeekologi. Dessa tre övergripande system bestämmer det mänskliga tillståndet, menar Strate, men de överlappar också med varandra och det sker med andra ord en kommunikation över skilda domäner:

In systems terms, the technological is nested within the biophysical, so that the biophysical is the environment of the technological, and the technological emerges out of the biohysical. And the symbolic is nested within the technological, so that the technological is the environment of the symbolic, and the symbolic emerges out of the technological. (75)

Strates tre system fungerar som omgivningar för varandra, eller åtminstone fungerar den bio-fysiska nivån som omgivning för de övriga två. Och eftersom en strukturerande omgivning och miljö är samma sak som ett medium - "Simply put, the terms 
medium and environment are synonyms, so studying media as media is synonymous with studying media as environments" (112) - organiserar sig den mänskliga tillvarons tre ordningar gentemot varandra i form av medier. Närmare bestämt, i en medieekologi.

Hur system organiseras i förhållande till varandra är förstås den stora frågan om man vill teoretisera teknisk agens utan att behöva hamna i teknikdeterminism. Ett system organiserar en omgivning, som i sin tur består av olika system - bio-fysiska, teknologiska, symboliska i Strates schema - som organiseras i relation till varandra som delsystem i den övergripande systemiska organisationen, samtidigt som dessa delsystem i sin tur organiserar en omgivning som består av en mängd internt relaterade system, som är delsystem, och så vidare. Det är denna komplexa organisation som konstituerar ett ekosystem. Strate påpekar att ett system alltid är mer än sina delar och att de delsystem som organiseras inom den övergripande systemiska organisationen - alltså inom ekosystemet - blir avhängiga denna övergripande organisation och därmed avhänder sig del av sin självständighet. Strate menar att medieekologier organiserar system inom system, i ett slags hierarkiska ordningar där vissa system bestämmer förutsättningarna för andra:

The idea of systems nested within other systems has its equivalent in the way that individual media together form a larger media environment, or in different levels of abstraction between, say, Facebook as a medium, within the web as a medium, within the internet as a medium, within the electronic media environment. (107).

På denna punkt uppvisar Strates resonemang - och egentligen hela den humanistiska medieekologin - en bristande teoretisk förståelse av ekologiska och cybernetiska processer. Vad menas med att ett system ger upp sin självständighet? Kan system vara självständiga? Vilket inflytande har delsystemen över helheten, och i vilken utsträckning går det att över huvud taget tänka sig ett system som inte är avhängigt andra system? Hur ordnar ett system ett annat? Och går det, som den humanistiska medieekologin tycks mena, att utpeka en väsentlig del av människan - en autonom, moralisk och fri vilja till exempel - som på ett kvalificerat vis står utanför inflytande från de delsystem som den organiserar?

Relationen mellan medium och omgivning, och den återkoppling och omkastning mellan figur och bakgrund som McLuhans mediebegrep opererar med, förutsätter en rekursiv kasualitet som inte kan konceptualiseras inom den begreppslighet som den humanistiska medieekologin opererar med. Här krävs den cybernetiska och 
systemteoretiska begreppslighet som i Hayles klassiska How We Became Posthuman (1999) utgör grunden för en posthumanistisk och distribuerad subjektivitet. Enligt den andra ordningens cybernetik och systemteori, tydligast formulerat genom Humberto Maturana och Franscisco Varelas autopoiesis-teori, opererar varje system självständigt, självgenererande och självorganiserande. Ett autopoietiskt system är slutet och upprättar genom den struktur som är dess organisation en distinktion mot omvärlden. Men, genom denna distinktion upprättas också en relation till samma omvärld, och denna relation styr i sin tur hur ett system organiserar sin struktur. Med andra ord spiller omvärlden alltid in i systemet, ett system är alltså i denna mening alltid delvis öppet. Det är denna inneboende ekologiska öppenhet och nödvändiga relation till omvärlden som Hayles tillskriver posthumanismen och Donna Haraway inskärper med sin symbiotiska emfas av systemteorin genom begreppet sympoiesis (sam-skapande, istället för Varela och Maturanas själv-skapande).

\section{Emergens och formell kausalitet}

Till skillnad från Strate, berör Cali i sin genomgång av medieekologins disciplinhistoria inte systemteoretiska aspekter i någon större utsträckning. Han vidhåller, precis som Postman, en sorts absolut humanism inom vilken det modernas autonomiserade kategorier och orsaksrelationer är entydiga. Om inte ett medium har sitt ursprung i en mekanistisk process, är det en mänsklig vilja som skapar det. Och bakom mekanistiska processer ligger alltid en mänsklig vilja. Strate för här däremot en mer nyanserad diskussion, framför allt genom ett försök att anpassa den klassiska kategorin formell orsak till en ekologisk begreppslighet.

Strate baserar sitt argument på de fyra typer av orsaker som utpekas i Aristoteles Metafysik: effektiv orsak, materiell orsak, final orsak och formell orsak. Effektiv orsak består av en effekts omedelbara och kausala ursprung. En materiell orsak bestäms av ett systems (och ett objekts) specifika materiella förutsättningar och en final orsak orienteras efter det syfte eller mål en process strävar mot. En formell orsak, slutligen, utgörs av den form eller det mönster som ett system (och ett objekt) utgör. Den formella orsaken i Aristoteles klassiska förståelse är ett systems (och ett objekts) inneboende och ideala ordning. Genom formella orsaksrelationer undersöker Strate möjligheten att tillskriva medier och tekniska system en dynamisk och relationell kausalitet som inte bara följer en förprogrammerad mekanistisk riktning, utan som också förmår respondera på en given situation och omkringliggande miljö. Från ett systemteoretiskt perspektiv handlar den formella orsaken om relationen mellan ett 
system och dess omgivningar, menar Strate, där omgivningen är den förutsättning ur vilken ett system framträder.

Här är återigen inflytandet från Gregory Batesons Steps to an Ecology of Mind (1972) påtagligt. Batesons cybernetiska konceptualisering av ett för allt levande sammanbindande mönster, ett "mönster som förbinder", samklingar med den mönsterigenkänning ("pattern recognition") som enligt Strate utgör hjärtat av medieekologins metod. Den formella orsaken, tänker sig Strate, är det mönster med vilket relationen mellan medium och omgivning organiseras. Med detta dock inte sagt att han går så långt som att tillmäta teknologier och medier ett kvalificerat aktörskap. När teknikhistoriker utpekar stigbygeln som feodalismens orsak, eller när Elizabeth Eisenstein i sin undersökning av tryckkulturer talar om tryckteknologierna som en historisk aktör, opererar vi på en figurativ nivå, menar Strate. Själva orsakssambanden är betydligt mer komplexa, och involverar förr eller senare en människa som så att säga sätter bollen i rullning.

Strates resonemang rimmar här illa med den systemteoretiska beskrivning av medier och miljöer som han tidigare har presenterat. Ändå vill han inte tala i termer av teknikdeterminism eller teknisk agens, delvis för att det framför allt är på denna punkt som medieekologin har ifrågasatts, men framför allt för att han menar att determinism inte beskriver de formella orsaksrelationer som medieekologin studerar. Inte heller är det tal om korrelation, även om sådan ofta förekommer. En ekologisk formell orsak tycks snarare implicera en relationell kausalitet. Hur denna sedan ska beskrivas är ju förstås den springande punkten. Och här blir också Strates argument något oklart.

Till viss del ligger Strates ekologiska inramning av formell orsak, som förutsätter ett mönster för en systemisk organisation, nära den cybernetiska förståelsen av emergens och autopoiesis. Det är Strate medveten om, även om han inte till fullo vill inkorporera det i sitt argument. Som Mark B. N. Hansen och Bruce Clarke påpekar i Emergence and Embodiment (2009) beskriver autopoiesis - i den mån vi diskuterar en i tid och rum situerad organism - emergenta processer i vilka system och omgivningar framträder gemensamt. Hansen menar att en systemisk organisation alltid är just en fråga om ett samskapande, i vad han talar om som en "system-omgivning hybrid" ("system-environment hybrid"). System och omgivning framträder alltså genom sig själva, tillsammans, och till synes spontant.

Om formella orsakssamband inte handlar om en teleologisk kausalitet, där ett system har ett inneboende mål för sin organisation, nedtecknat genom en skapares 
(gudomliga eller inte) formgivning, kan det möjligen vara relevant att tala om en teleonomisk process, menar Strate. Det vill säga, den slumpmässigt uppkomna organisationen av ett ekosystem, och av en medieekologi, förefaller ha en inneboende riktning och vilja, men denna riktning och vilja är endast retroaktivt igenkännbar. Här tycks Strate dock förutsätta en position utanför medieekologins rekursiva operationer, något som alltså inte ryms inom ett systemteoretiskt begrepp som emergens. Emergens opererar just genom en rekursiv kausalitet. Och detta innebär slutligen att alla former av absolut autonomi, självreglering och ursprunglig vilja måste överges. Vi kan fortfarande tala om autonomi, men rekursiv autonomi är processuell: loopen är sluten men öppnar sig hela tiden för omvärlden.

Så långt som till en rekursiv autonomi vill inte Strate gå. Han tycks i slutändan mena att en teleonomisk kausalitet tillskrivs retroaktivt, av ett mänskligt subjekt. Precis som med tryckpressen, stigbygeln och McLuhans mediebegrepp generellt, är det för Strates humanistiska medieekologi fråga om en figurativ tolkning av emergens. En rekursiv kausalitet skulle medföra att det mönster som organiserar relationen mellan medium och omgivning inte föregår denna relation. Mönsterigenkänningen mister därmed sin förklarande funktion. Strate tycks här alltså mena att någon form av effektiv orsak krävs för att kunna tala om ett mediums organiserande mönster som en förklaring till en given relation mellan system och omgivning. Det mönster som medieekologin identifierar är inte bara ett resultat av informationsprocessens negativa återkoppling genom vilken ett system organiserar omgivningen (och därmed reducerar bruset). Medieekologin identifierar också mönster som besitter en formell och föreskrivande orsaksfunktion menar han: "it is the pattern of complex interactions that is the cause of whatever effects emerge out of or as the system".

Strates position blir extremt vacklande. Han vill inte fullt ut erkänna att den organisation - det mönster - som strukturerar organismer uppträder genom situerade och emergenta processer, det vill säga genom rekursion. Men han vill heller inte påstå att en formell orsak måste förankras i en mänsklig formgivares intentionalitet, och på så vis föregå relationen mellan ett medium och en omgivning. Samtidigt hävdar han att dessa mönster ändå har en föreskrivande funktion, som inte bara kan reduceras till evolutionens urval genom negativ återkoppling. De är inte bara mönster som förbinder, utan också mönster som föreskriver ("patterns that direct"), menar State. Här lutar han sig återigen mot Batesons "mönster som förbinder" som opererar med en utvidgad uppfattning om medvetande och perception, och inbegri- 
per långt mer än antropocentriska kategorier, men som likväl, åtminstone stundtals, tycks implicera ett slags transcendent holism som styrande princip. Med andra ord utverkar dessa mönster ett slags potentiellt icke-mänsklig agens i form av en organisation som kausalt föregår omgivningen. Frågan är hur detta mönster då kan förklaras, utan rekursion, med mindre än att det tillskrivs något slags övergripande (transcendent) plan för tillvaron?

\section{Post-rationell eko-logik}

Samtidigt som Strate menar att system- och emergensteorier som just autopoiesis, men även Buckminster Fullers synergibegrepp, behövs för att beräkna återkoppling och en icke-linjär temporalitet, finns alltså en tydlig ovilja att acceptera de posthumanistiska implikationer som en emergent och rekursiv autonomi inbegriper. Mot slutet av sin framställning skisserar Strate en "media eko-logik" ("media ecologic") som i ett icke-dualistiskt system söker sammanföra en traditionell rationalism med Fritjof Capras Gaia-inspirerade ekologiska komplexitetstänkande. Ett "media eko-logiskt" tänkande är varken dialogiskt eller monologist, det är varken intuitivt eller rationellt, utan post-rationellt, menar Strate. I denna mening representerar mönsterigenkänningen inte endast ett spontant och intuitivt tänkande, men den är heller inte ett renodlat rationellt tänkande som inte tillerkänner intuitionen ett verksamt inflytande. Istället upprätthåller det post-rationella en balans mellan intuition och rationalitet, och integrerar alltså ett kritiskt och analytiskt tänkande med andra former av kunskap och kognition.

En post-rationell eko-logik låter förstås mycket lovande, inte minst för en undersökningsmetod som också vill beräkna förkroppsligad, materiell och affektiv erfarenhetsproduktion. Strate går inte in på exakt vilka icke-rationella former av kognition - utöver intuition - som han menar ingår i en eko-logik. Resonemanget bygger emellertid på det slags "utvidgat medvetande" teorier som just Capras version av Gaia-hypotesen bygger på. Dessa teorier förutskickar att ett kognitivt omedvetet, som opererar i hastigheter som överstiger den mänskliga medvetna perceptionen, går att härleda till ett utvidgat och övergripande medvetande. Frågan är då återigen hur de mönster som den medieekologiska metoden igenkänner uppstår? En eko-logiskt intuitiv och spontan organisation uppstår inte som ett led i ett linjärt, rationellt tänkande. Men om mönstret inte går att härleda till en rationell, mänsklig aktör, tillskrivs det likväl ett medvetande, om än Gaia-teorins utvidgade medvetna organism. 
På så vis, så länge det handlar om icke-teknologiska miljöer och omgivningar, tillåter den humanistiska medieekologin en icke-mänsklig, strukturerande agens, som i sin tur organiseras enligt Gaia-hypotesens utvidgade medvetande som strävar efter ett slags hållbar och homeostatisk evolution. Slutsatsen tycks vara att de mönster som strukturerar ett medium kan vara formellt orsakade av Gaia-organismens övergripande organisation, om det handlar om ett medium som inte är en teknologi.

En viss uppluckring av den strikta humanism som Postman, liksom i hög grad Cali, fastslår, tycks alltså ske genom att Strate i sin disciplinhistoria inför andra ordningens cybernetiska systemteorier, liksom de komplexitets- och kognitionsteorier som utvecklats med dessa som grund. Men genom att han samtidigt inte vill tala om rekursiv kausalitet som en möjlighet förblir den humanistiska medieekologin, trots ambitionen att utpeka en på emergensteorin modellerad formell kausalitet, oförmögen att tala om teknisk agens utan att hamna i en enkel teknikdeterminism.

Och som vi har sett, är det just här gränsen mellan en humanistisk och posthumanistisk medieekologi dras. Även om Strate diskuterar ekologier och övergripande omgivningar i termer av medier, och genom kognitionsteori och Gaiahypotesen inkluderar såväl kognitivt omedvetna som icke-mänskliga aspekter i de mönsterigenkänningar som metoden genererar, dras det likväl en absolut gräns mot tekniska system och teknologier som medskapare och aktörer. För Strate - och för den humanistiska medieekologin - tycks de tekniska systemens inflytande och affektiva kraft alltid vara avhängig en effektiv kausalitet, där ett organiserande mönster tillskrivs en transcendent vilja, mänsklig eller inte.

Det är i detta hänseende inte oviktigt att Strate i sin genomgång av medieekologins historia närmast historierevisionistisk korrigerar Raymond Arlos korta manifest för en ny medieekologisk disciplin, publicerad i Radical Software 1971 - för övrigt utgiven ungefär samtidigt som Postmans definition publiceras. Där Arlo i originalet pläderar för medieekologi som "[ $t]$ he study of a medium of communication and its affect upon other media/society" genomför Strate i sin presentation helt ogenerat en ändring av "affect" till "effect". Han är till och med medveten om att han gör det (om än möjligen omedveten om de bakomliggande orsakerna till sitt agerande) och tillägger inom parentes: "in this quote I have taken the liberty of correcting the spelling of effect, which appears as affect in the original".

Som disciplinhistoria blir det naturligtvis särskilt olyckligt att den nymaterialistiskt och posthumanistiskt orienterade grenen av medieekologin här i ett svep trollas bort, som vore dess förståelse av den mediala infrastrukturens omvärlds- 
formerande inflytande endast ett resultat av ett enkelt stavfel. Samtidigt tycks greppet dessvärre vara talande för det projekt som för närvarande drivs inom utgivningsserien "Understanding Media Ecology". I framtiden får vi hoppas att redaktör Strate kan motverka den språkpolisiära impulsen, oavsett på vilken systemisk nivå den determinerar honom. 